\title{
DOES FRACTIONAL RESERVE BANKING SYSTEM EXIST IN INDONESIAN ISLAMIC BANKING?
}

\author{
Yaser Taufik Syamlan ${ }^{1}$ and Nur Istiana ${ }^{2}$ \\ ${ }^{1}$ STEI TAZKIA, Indonesia. Email: yasersyamlan@tazkia.ac.id \\ ${ }^{2}$ STEI TAZKIA, Indonesia. Email: nuristiana25@gmail.com
}

\begin{abstract}
Fractional Reserve Banking is a banking and financial system used in most countries around the world. This research aims to look at its impact empirically and at the contributions given from the components of fractional reserve banking against inflation that occurs in Sharia Commercial Banks and Sharia Business Unit. The fractional reserve banking components covered in these studies are statutory reserve requirements, total deposit, total financing, Mismatch Ratio, and total non-performing financing. This research used VAR VECM and ECM as analysis tools and collected secondary data from Indonesia's Financial Service Authority (OJK) that spanned from June 2014 to September 2018. The results of this research found that the largest contributor on Sharia Commercial Bank (BUS) is the Statutory Reserve Requirement while in sharia Business Unit the results showed that Third Party Fund and Mismatch ratio provided the greatest contributions against inflation. Moreover, it shows that fractional reserve banking occurred both in UUS and BUS. To prevent fractional reserve banking from affecting in the future, the control of mismatch and introducing the irrevocable investment account might be the solutions.
\end{abstract}

Keywords: Fractional Reserve Banking; Islamic Banking; Mismatch; Inflation. JEL Classification: B22; B53; E51.

Received : October 10, 2018

Revised : November 25, 2018

Accepted : November 30, 2018 


\section{INTRODUCTION}

Fractional Reserve Banking System is a banking and financial system used by most countries in the world. Islamic banking and finance also operates with this principle (Meera \& Larbani, 2006). In Fractional Reserve Banking, banks become intermediaries between the surplus units (depositors) and the deficit units (debtors) by maintaining a small portion of depositor's money, with the remainder being loaned to debtors so as to maximize profits within a certain period (Syamlan, 2016). In banking, the process of lending money can also be said to be the creation of credit (Hasan, 2008). Whenever the bank lends money to the debtor, the bank creates money. Accordingly, the money supply increases. If the amount of money grows increasingly in quantities and continues to increase it will trigger inflation.

In the Quantity of Money theory that was first introduced by Hendri Thronton, there was a relationship between the money supply, the price quote, and the level of purchasing power (Ishaq \& Mahjabeen, 2015). This theory explains that the money supply has a positive relationship with the price and a negative relationship with the level of purchasing power. Furthermore, this theory confirms the banking business cycle that provides financing, in that when banks provide financing, which is the same as money creation, the money supply will then also increase. More and more growth of money will affect prices. The greater the money supply grows, the higher the price will become. High prices will result in a low purchasing power. If this situation takes place continuously, it will eventually cause inflation (Bagus, 2012).

The Fractional Reserve Banking system has a serious impact on the structure of ownership in the economy because this system creates an ownership without any risk taking. As such, it also contains elements of usury which are prohibited in Islam (Meera \& Larbani, 2009). When a financing customer fails to pay his obligations, the bank will take the customer's assets. Automatically, the assets originally owned by the customer with an easy transfer of ownership will soon belong to the bank. The transfer of ownership is determined because the Fractional Reserve Banking system has become a system used by most banks in the world. Such a system can also lead to high levels of Non-Performing Financing in Islamic banking. To illustrate, this condition occurs when banks provide financing to customers who are at the time unable to pay back the financing provided. In addition, the Fractional Reserve Banking system could also cause a liquidity mismatch triggering a chain reaction (Bagus \& Howden, 2009; Bagus, et al., 2015; and Syamlan, 2016). By then, the liquidity management process relies heavily on new depositors and will continuously revolve. If the new depositor's funds are insufficient, then the ratio of the liquidity mismatch will be smaller, signifying that the bank is unable to meet its liquidity obligations. 


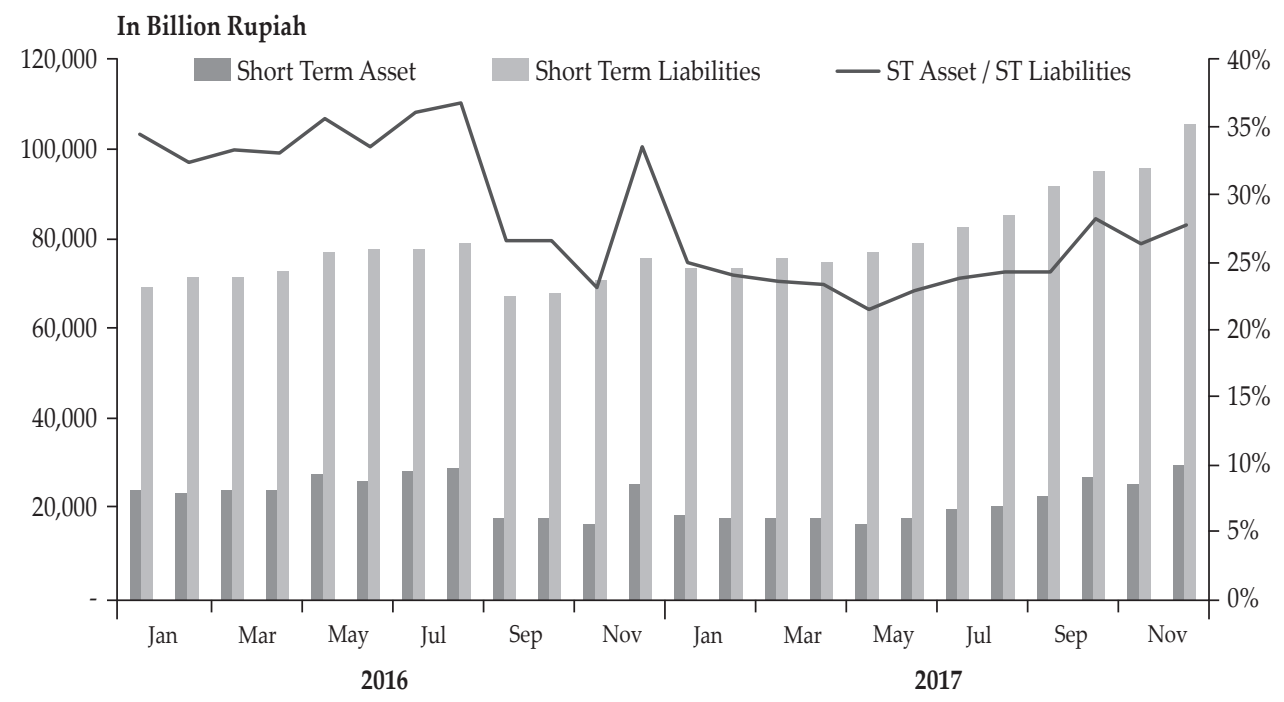

Source: Islamic Banking Statistics, (OJK, 2017)

Figure 1. Short-term Mismatch in Indonesian Islamic Banking

According to some data from Indonesia's Financial Service Authority (OJK), the mismatch ratio in Islamic banks for the past two years is still perceived to be quite volatile. The mismatch rate shows that Islamic banks are only able to guarantee customer's liquidity in the amount of the ratio; whereas, the rest becomes liquidity risk that must be borne by Islamic banks. According to the data, at the end of 2017 Islamic banks were only able to guarantee around 30\% customer's liquidity. It is indicative of the bank having to bear a liquidity risk of $70 \%$. Likewise, the Sharia Business Unit in Indonesia has shared similar experience. According to data from OJK, the liquidity risk that must be borne by the Sharia Business Unit reaches more than $70 \%$ by the end of 2017 . As long as the mismatch ratio in the Sharia Commercial Bank and Sharia Business Unit still exists, the financial institution would still be justified to implement the Fractional Reserve Banking system.

Based on the aforementioned background, it can be concluded that the objectives of this study are directed at proving that the Islamic banks, i.e., the Bank Umum Syariah - BUS (Full Fledged Islamic Bank) and Unit Usaha Syariah -UUS (Islamic Window), are both in fact practicing the fractional reserve banking. Moreover, this study will also analyze the effects of shocks of fractional reserve banking components on Islamic Commercial Banks and Sharia Business Units on inflation and investigating the influence and which contribution is greater between the Sharia Commercial Bank and the Sharia Business Unit on inflation. 


\section{LITERATURE REVIEW}

\subsection{Money in Islam and the Historical Perspective of Banking Industry}

Islam considers money as the medium of exchange (Iqbal \& Mirakhor, 2013). In the historical perspective, the history of money in Islam started from the time the Roman Byzantine created the denarius (gold coin) and mimicked in the times of Prophet Muhammad (pbuh) (Meera \& Larbani, 2006). The reserve banking system is divided into two: (1) "100\% Reserve Banking Systems" or 100\% RBS (Bagus, 2012) and (2) "Fractional Reserve Banking System" or FRBS (Bagus \& Howden, 2010). Based on the history, economists have recorded that the birth of the first banking system was in the era of Roman Emperor (500BC), which was operated under the $100 \%$ RBS (Ochaita, 2010). Fast forward into the $16^{\text {th }}$ century, this concept was also flourished in Netherlands \& Germany when Bank of Amsterdam was established in 1609 and Bank of Hamburg in 1619. Both financial institutions offered pure safekeeping deposit product to their customer (Askari \& Krichene, 2016). At the same time, in the UK The Goldsmith Banking System (GBS) was founded. The GBS was known as the first FRBS in the world. GBS offered deposit product to customer by giving interest, thus eased them to construct financing to the customer (Quinn, 1997; and Selgin, 2012). The FRBS that was initiated by GBS pushed the bank to exploit the depositor's funds to make profit by way of explosive credit financing and affecting the money supply in the economy.

\subsection{Theoretical Perspective of FRBS in Islamic Bank}

Both conventional banking (CB) and Islamic Banking (IB) have practiced this FRBS. Islamic banks have recently faced some philosophical problem, where epistemology-speaking, they use empirical knowledge of conventional banking (CB) to be filtered with the Islamic value (Furqani \& Haneef, 2012; Javaid, 2015; Javaid \& Ul Hassan, 2013; Syamlan, 2016). As a result, the operational side of IB is still similar to the $\mathrm{CB}$ in terms of liquidity management. Both are now using the "fractional reserve banking system" (FRBS) as the basis of exploiting the depositor's funds (García, Cibils, \& Maino, 2004; Hanif, 2011; Illiyin \& Ascarya, 2013; Wan Ibrahim \& Ismail, 2015). The practice of FRBS, moreover, has been condemned by economists from various school of economics, including that of Chicago, Austria, as well as the positive money from UK (De Soto, 2006; and Lainà, 2015). In addition, Islamic scholars argued that it is unlawful to contravene to the Islamic value of Maqasid sharia (Hasan, 2008, 2011, Meera \& Larbani, 2006, 2009).

The exploitation may increase the liquidity risk by creating long-term credit by using short-term fund and it will end up by rush money whenever a recession occurs (Bagus, Gabriel, \& Howden, 2016; Bagus \& Howden, 2009, 2012b, 2016). Moreover, the FRBS application in Islamic bank creates transfer of ownership from depositor's fund to Islamic bank asset and, at the end, channeling it to the creditor in form of projects (Meera \& Larbani, 2009). FRBS, which is operated on the basis of non-neutrality of money, also triggers the growth of goods price and at the end might escalate the money supply (Angel, 2016; Bagus, 2012; Block \& Garschina, 1996; Cochran \& Call, 1998, 2000; Meera \& Larbani, 2009). 


\subsection{Fractional Reserve Banking System Proxy in Islamic Bank and Its Effect on Inflation}

\subsubsection{The Third Party Funding}

Ontologically, the theory of deposit states that a deposit demand genuinely should be treated as a mere custody (Bagus \& Howden, 2012b). Unfortunately, the epistemological error took place, and the banks have nowadays used the theory of irregular deposit rather than regular deposit. Therefore in the practical side, all of the deposit is used to fund the bank to finance, leaving only a small fraction of deposit to sustain the bank (Bagus et al., 2016, 2015; Barnett II \& Block, 2009; De Soto, 1998; Nair, 2013). The fallacy of theory of deposit occurs not only in conventional banks, but also in Islamic banks. The delusion ensued on the pronouncement of the wadiah yad dhamanah, instead of promoting wadiah yad amanah in Islamic Bank daily operation (Farooq, 2011). Furthermore, Islamic banks also offer deposit product under contract of Mudharabah (investment contract). Once again, the operational side of Mudharabah does not comply with the legal definition of deposit since it offers a "capital certainty" (Archer \& Karim, 2009, 2012). The irregular deposit as the heart of the fractional reserve banking system will at the end trigger the fragility of economic system because it creates inflammatory effects of goods price (Bagus \& Howden, 2009; Syamlan, 2018).

According to Austrian School economists, irregular deposit also triggers the economic downturn due to an escalation of goods price. In this research, such a scheme is observed to cause another problem called liquidity mismatch. Liquidity mismatch is defined as using short-term deposits to finance and channeling longterm projects into projects by virtue of credit. As an example, if A deposits his money in an Islamic bank for one year, the Islamic bank in this context should precisely extend this deposit for 1-year financing so that no mismatch will take place. However, based on the previously mentioned of the philosophical perspective of liquidity management of Islamic bank still mimicking the conventional counterpart, Islamic banks actually exercise the liquidity mismatch. To illustrate, instead of intermediating 1 year deposit to a 1-year financing, Islamic banks offer a 2-year financing (Barnett II \& Block, 2009). The liquidity mismatch at the end will also cause the inflation since the bank exploits the short-term deposit to finance long-term project. When a project is financed or if, for some reason banks provide financing for consumptive purposes, such practices will intensify money supply, which in the end will increase goods price (Bagus \& Howden, 2012a).

\subsubsection{Bank Financing}

Loan or financing is an effort of the bank to exchange the present goods with the future goods (Bagus \& Howden, 2009; Barnett II \& Block, 2009). In this case, Islamic banks do so using Islamic contract. For example, if a debtor comes to an Islamic bank and wants to acquire an asset, the Islamic bank then uses the murabahah financing to buy the asset and transact as exchange money paid by the debtor by way of monthly installments. Alternatively, in the syirkah financing case, Islamic banks give the money to the debtor to run their potential project and install back both the principal and the profit shared from that project in the future. Moreover, the process of providing financing to the debtor here, according to most Austrian 
school economists, might create inflation. That said, the financing given to the debtor creates more purchasing power and potentially inflate the supply of money in the market (Bagus \& Howden, 2016).

\subsubsection{The Non-Performing Financing}

As per economic cycle, the rise of deposit will subsequently hike the financing and non-performing financing. Specifically, the focus is on the relationship of nonperforming financing to the economy, especially that associated with inflation. The non-performing financing occurs when an Islamic bank confronts a customer who fails to pay for their debts to the bank. When it happens, the non-performing financing rate hikes and in the end will affect the decision of depositors: whether or not they should withdraw their money. As for depositors withdrawing their money from the banking system, it will increase the amount of money circulating in the economy, which again will inflate the goods price. Moreover, the nonperforming financing indirectly distresses the economy, where a massive nonperforming financing will end up with the rise of interest rate that controlled by central bank. According to Ascarya (2013, 2014), the period where central bank rises the interest rate occurs in the time when the goods price inflates.

\subsection{Previous Studies}

This research is basically inspired by the works of several researchers from western countries who are concerned of the bad impact of fractional reserve banking to the banking industry and the economy. Among the researchers often cited are Bagus et al., (2016, 2015); Bagus \& Howden (2009); Barnett II \& Block (2009); Davidson (2015). Their works were published in Scopus-indexed journals as well as an ABS journal called Journal of Business Ethics. Furthermore, this study reflects on works published in Review of Austrian Economics, such as those of De Soto (1995). Additionally, this research refers to the following papers:

1. Ahmed's (2011) research on the relationship of GDP, Money Supply and Consumer Price Index by using Granger Causality test. The study found that the correlations between the three variables were strong with value of 0.93 . In the long run, the price level is found to be co-integrated. The causation only takes place to the money supply and price, meaning that when money supply was abundant in the economy, the purchasing power arose, and there was no reverse causation (price to money supply) taking place in the end. The more money supply, the more inflation and the probability of GDP climbing. Some interesting points of the research are as follows: (1) At the first subperiod (1960-1989), the GDP was low since the political imbalance resulting in a civil war. Moreover, at the time, the Foreign Direct Investment was mismanaged. The economic condition of Sudan was not developed very well because of the natural hazard; (2) the slow economy finally improved on the second phase (1990-2005). The government made strategic improvement by deploying Islamic finance in the country's economy. They also set up a conservative statutory reserve of $10 \%$ from third party deposit. Moreover, the central bank of Sudan pushes all banks to have cash reserves of $26 \%$ from $30 \%$ to ease the 
money supply. Sudan has such conservative policies to control money supply compared to Indonesia by pegging $10 \%$ of reserve ratio to be deposited in the Central Bank. Comparatively speaking, Bank Indonesia (the central bank of Indonesia) would require the banks to deposit $4 \%$ of the third party funds. The central bank of Sudan also tried to stabilize the economy by setting cash ratio of $26 \%$ of the deposited money for reserve. This means that the Financing to Deposit Ratio (FDR) of Sudan's bank was set to 74\%, which was lower than the FDR of Indonesia's bank at $80 \%$.

2. Hanif's (2011) literature review ensures that most of Islamic banks are operating under dual banking system. Thus, they should obey all rules that are made for all banking in the nation. Therefore, there is a FractRBS that is exercised in both conventional and Islamic banks. FractRBS depends on the Statutory Reserve Requirement (SRR) policy determined by the central bank. The greater SRR, the lower fund supplied into the economic system, and the lower financing can be supplied with stipulated contracts. It is true that FractRBS might hike the supply of money in the system, but economists seem to forget that in the recess, it will cause the severe turmoil since it triggers the insufficient liquidity and a possible cause to 'burn down' the banks.

3. Ishaq \& Mahjabeen (2015), Panel Data Analysis, total deposit \& total financing as the independent variable and non-performing financing as well as inflation as independent variables. After the recent financial distresses, extensive debate was made on the modes of financing and Islamic modes of financing was introduced as an antidote. This study discussed that it is the nature of money not the modes of using it, which causes distresses. Current monetary system is based on the fiat money and hence on fractional reserve banking which has serious implication to the ownership structure in economy. To analyze this phenomenon, the sample of 25 banks has taken from Karachi stock exchange 100 index for the period of 2008-2012. In panel data analysis, the study used the linear regression and correlation coefficient models to find relationship between the variables. It is found that money expansion through credit creation leads to inflation and nonperforming loans that affects the ownership.

4. Hassan, Echchabi, \& Aziz (2015) conducted quantitative research using Pooled Ordinary Least Square (POLS). The study was more specific than the first one on fractional reserve banking, e.g., as in the amount of deposit and financing put as the Independent variable to calculate the Price Stability in Gulf Cooperation Countries (GCC). The object of the study was Qatar, Kuwait, Oman, Saudi Arabia and UAE. Specifically, the authors use the debt growth as a representative of fractional reserve banking and regress it to inflation growth. The data range of the study was from 2008 to 2013 using Pooled Ordinary Least Square. The study found that the debt growth represented by the growth of deposit and loan is not significant to boost price level. The authors suggest a larger data span and more GCC countries to be included to have more comprehensive result. Moreover, another macroeconomic variable also needed to have better understanding of the impact of fractional reserve banking. Authors provide interesting conclusions by stating that in GCC the non-significant result came from the behavior of the market player in GCC in considering the money. The GCC people consider money as the mere of 
medium of exchange. The paper also shows that such a result is because of the vast development of Islamic banking and finance on the region and the deep knowledge and understanding of the people in the field of fiqh muamalah.

5. Syamlan's (2016) research is aimed to compare the epistemological bases to the mindset of Islamic Banks and attempt to drive the philosophy in practical operation whether it is based on the Fractional Reserve Banking System (RBS) or $100 \%$ RBS and analyze the challenges in deploying the $100 \%$ RBS. Based on the epistemological analysis of money and the business cycle as well as the views of Islamic scholars, 100\%RBS should be the best for Islamic Bank.

\section{METHODOLOGY}

\subsection{Data}

Secondary data were used in this study in form of monthly time series during the period of June 2014 - September 2018. The data were obtained through the official websites of the OJK and Bank Indonesia (BI).

\subsection{Operational Variables}

This study used a quantitative approach with Vector Autoregression (VAR)/ Vector Error Correction Model (VECM) method. The data were inflation growth, growth of third party funds, financing disbursement, non-performing financing of banks both sharia on commercial banks, and sharia business units, as well as the mismatch ratio in sharia banks and sharia business units. To analyze the Fractional Reserve Banking system in Sharia Commercial Banks and Sharia Business Units, the following VAR/VECM as well as ECM equations are used:

$$
\begin{aligned}
& \text { InfBUSi }=\alpha 0+\alpha 1 \mathrm{RRi}+\alpha 2 \mathrm{LnTPFi}+\alpha 3 \mathrm{MISi}+\alpha 4 \mathrm{LnTFi}+\alpha 5 \mathrm{NPFi}+\mu \mathrm{t} \\
& \text { InfUUSi }=\alpha 0+\alpha 1 \mathrm{RRi}+\alpha 2 \mathrm{DPKi}+\alpha 3 \mathrm{MISi}+\alpha 4 \mathrm{LnTFi}+\alpha 5 \mathrm{LnNPFi}+\varepsilon \mathrm{t}
\end{aligned}
$$

where:

- $\quad$ InfBUSi = Inflation caused by the fractional reserve banking system in Islamic Commercial Banks. The data were taken from yearly data inflation from SEKI BI.

- InfUUSi = Inflation caused by the fractional reserve banking system in the Sharia Business Unit. The data were taken from monthly data inflation from SEKI BI.

- $\quad$ SRR = Minimum Mandatory Current Account or Reserve Requirement. The data were collected from the decree issued by Bank Indonesia during the observed period.

- $\quad$ LnTPF = Third Party Funds in the form of natural logarithms (ln). The data were taken from monthly Statistics of Islamic Banks regularly issued by OJK for both Unit Usaha Syariah (Islamic Windows) and Bank Umum Syariah (Islamic Full Fledged Bank).

- $\quad$ MIS = Mismatch Ratio. The data were taken from monthly data of Islamic Bank Statistics that regularly issued by OJK for both Unit Usaha Syariah (Islamic Windows) and Bank Umum Syariah (Islamic Full Fledged Bank) 
- $\quad$ LnTF $=$ Total Financing in the form of natural logarithms (ln). The data were taken from monthly data of Islamic Bank Statistics that regularly issued by OJK for both Unit Usaha Syariah (Islamic Windows) and Bank Umum Syariah (Islamic Full Fledged Bank)

- $\quad$ LnNPF BUS = Non-performing Financing. The data were taken from monthly data of Islamic Bank Statistics that regularly issued by OJK for both Unit Usaha Syariah (Islamic Windows) and Bank Umum Syariah (Islamic Full Fledged Bank)

- $\mu$ and $\varepsilon=$ Error

\subsection{VAR/VECM}

Below is the diagram that shows the process of VAR - VECM:

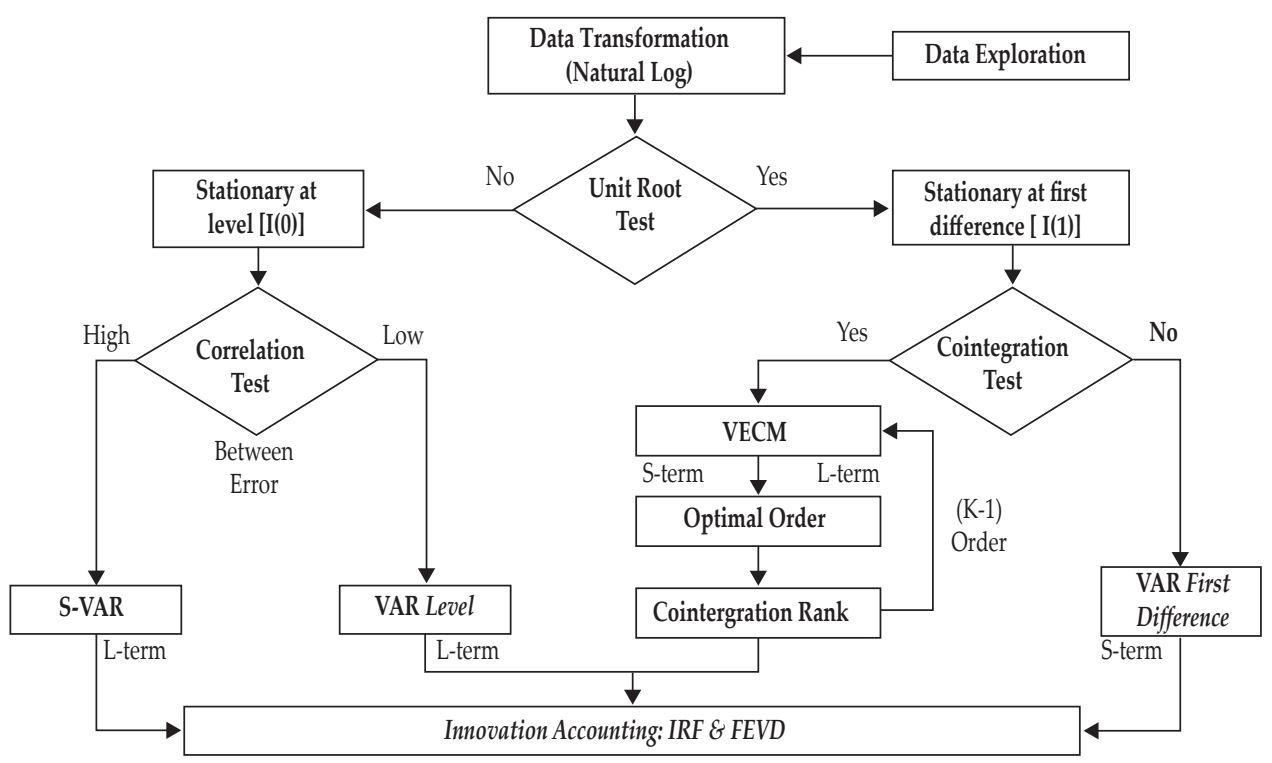

Sources: (Illiyin \& Ascarya, 2013)

Figure 2. The Process of VAR / VECM

Based on the above figure, the VAR/VECM begins with the collecting data and transform it by natural log since the data notations is vary (some of them in percentage and some of the in rupiah) to obtain consistent and valid results. The first test conducted was the unit root test, to seek whether the data is stationary or still contain trends. If the data were stationary at levels, then VAR can be conducted at level. VAR level can estimate the long-term relationship between variables. If data were not stationary at level, then the data should be reduced at the first level (first difference), which reflects the difference or changes in data level. If the data were stationary at first difference, then the data will be tested whether there is cointegration between variables. If there is no co-integration between variables exist, 
then VAR can only be done at the first difference, and it can only estimate the shortterm relationship between variables. If there is co-integration between variables, then VECM can be done using data level to obtain long-term relationship between variables. VECM can estimate the short-term and long-term relationship between variables. Innovation accounting for the level VAR and VECM will be meaningful for the long-term relationships.

\subsection{ECM}

The Error Correction Model (ECM) was established to cater the spurious regression. According to Enders (2004) if a regression contain is resulted from a set of variable that is not stationary in level, the $t$ - test value from the calculation process cannot be believed. To solve the problem ECM can be implemented with below procedures:

1. Testing the unit root of the series data to determine the order. Moreover, as per the condition of ECM which stated by Enders (2004), the data should be stationary at the (I) difference.

2. Estimating the long run relationship.

3. Estimating the short run relationship by making the residual data and testing the stationary of data. If residual data stationary at level, the set of variables can be continued to the process of estimating short - run relationship.

4. Both on the long and short run, the F - statistic result should be checked. If the $\mathrm{F}$ - statistic below the confidence level 5\%, the long and short run equation can be analyzing further.

\section{RESULTS AND ANALYSIS}

\subsection{VAR / VECM \& ECM Results}

Table 1 shows the first test conducted in this study using the data stationary test. In the method used by the writer, the stationary data is shown by the ADF (Augmented Dickey Fuller) Test with a confidence level of 5\%. The data can be classified as stationary if the t-ADF value is smaller than the critical value of MacKinnon. Unit Root Test is tested at the level up to the first difference. Based on the unit root test results in Table 1, it can be stated that all variables stationary at the level of the First Difference.

Moreover, based on the Tables 2 and 3, which also tested the unit root of the equation of BUS and UUS, it is found that these two model is not stationary at level that is meant these equations can be proceeded to the calculating the long run relationship of ECM.

Table 3 is the result of the stability test. In Table 2, the equation for BUS in the first model of modulus shows the results in the range of $0.2439-0.625120$ which lies in lag 1_2. In the BUS equation, the estimated VAR will be used in stable IRF and FEVD analysis because the modulus is smaller than one $(<1)$. Whereas the UUS equation also has a stable result because the results of the stability test in the UUS equation shows a range of $0.04463-0.994154$ but the location of the lag in the UUS equation is different from the BUS equation which is located at lag 1_2. 
Table 4 shows the results of the optimum lag test performed to determine the optimum lag in the VAR model equation in the study. In Table 3 it is shown that the maximum lag on the stability test leads to the lag $5 \& 6$. So it can be concluded that the optimum lag in the equation of BUS and UUS is at lag 5 for BUS and lag 6 for UUS.

Tables 5 and 6 are the results of cointegration tests or in another word are statistical tests performed when the data turned out to be stationary at the first difference level. This test is done to see the possibility of cointegration between variables. This testing criterion is based on the comparisons of trace statistics values with critical values. Cointegration tests are accepted if the values in trace statistics are greater than the critical values. In the cointegration test, there is an asterisk symbol $\left(^{*}\right)$ that addresses the number of cointegration between variables. Table 5 shows 6 cointegration between the variables indicated by 6 asterisk symbols on the test results. Then, with the cointegration between variables, the analysis can be proceeded to the VECM model. Likewise with the cointegration results on UUS, in table 6 there is 3 asterisk symbols that is shown in the results of the cointegration test, which means that the analysis of the UUS equation can be continued to the VECM model testing.

Moreover, moving on the ECM cointegration test that shown in Tables 7 and 8 , based on the unit root test of newly made variable namely residual BUS and residual UUS, both test give a same result of stationary at level for both residual BUS and UUS. It means that this research can be proceeded to calculate the short run relationship of BUS \& UUS Model.

Table 9 is the result of the VECM test on the BUS model. These results show that this research may not lead to a long-term balance. This is indicated by the value of the Error Correction Term (ECM) with have no negative sign (-). It is quite surprising that all variables may not meet its equilibrium in the long run, which means the Islamic bank in Indonesia in need of business model transformation. In the short run relationship, only TPF in lag 1-5, NPF BUS lag 4, and Mismatch BUS lag 4 who may meet to its equilibrium. The rest of observed variables based on the VECM result may not meet its equilibrium. Moreover, discussing on the result of Table 10, of UUS Model the only variables that will end up with the equilibrium is mismatch with adjustment speed of $9.8 \%$. however, in the short run relationship, only SRR lag 1 to 4, UUSTPF lag 1 to 5 and UUS NPF lag 3 to 4.

\subsection{Analysis}

To answer the first research question that tries to prove whether the Indonesian IB's are doing the FRBS, we refer to the Table 10 to 13 that are taken from the ECM result. Refer to the table 10 in the long-term analysis from BUS Model, based in the t-statistic calculation that is conducted by the Eviews, SRR and Mismatch are significant to the Inflation. The rest is not significant to the inflation. Moreover, when central bank increase SRR for Islamic Bank for 1\%, it will escalate the aggregate good price by $0.18 \%$. Besides that, when the mismatch gap in BUS upsurge $1 \%$ the inflation will also expand $0.0407 \%$. These results are in line with what has been written by the previous research. Bagus and Howden $(2009,2012,2016)$ stated exactly the same with the result; the fractional reserve banking which represents 
by the SRR and mismatch affects the economy by virtue of the change of inflation. Moving on the BUS model short run relationship, SRR also still have significant impact to the Inflation and so NPFBUS impact it. In this case the effect of SRR in the short run is slightly lower than the long run. Every $1 \%$ increase of SRR, the inflation will also increase by $0.016 \%$; or in other word, this short-run relationship has a $0.0002 \%$ less impact to the short run relationship. Besides the SRR, NPF BUS also has a significant effect to the inflation. Every $1 \%$ increase of NPFBUS, the inflation is actually decrease $0.022 \%$. To explain this unique phenomenon, we can refer to the work by Ascarya (2014). As elaborated in the literature review, when the NPF increases when the economy turmoil happened. In that sense, the central bank will increase the interest rate due to the liquidity shortage as well as to cut the inflation down.

Moving on the UUS Model (Table 12), in the long run 4 variables namely SRR, UUSTPF, UUSFINANCING, and UUSMISSMATCH have a significant effect to the Inflation. The most influential variable that have bigger coefficient are UUSFinancing, UUSTPF, UUSMISSMATCH and SRR. Every $1 \%$ increase of UUSTPF and SRR, will also increase the inflation by $11 \%$ and $0.028 \%$. However, the UUSFINANCING and UUSMISSMATCH have adverse effect to Inflation since every $1 \%$ increase of both variables might decrease inflation by $11.07 \%$ and $0.08 \%$. In this case, there is possibility that an increase of third party fund in UUS cannot be channeled directly to the financing or in the other word it might be better option for them to utilize fund other than financing i.e. Money market. In the short run (Table 13), only SRR, UUSTPF, and UUSMISSMATCH which have significant impact to the inflation. Every $1 \%$ increase of it will subsequently increase inflation $0.017 \%$ (SRR) and $0.065 \%$ (UUSTPF). Meanwhile, the mismatch in the short run might lower the inflation by $0.078 \%$ in every $1 \%$ increase.

All in all, table 12 also showed that both BUS and UUS exercise the FRBS. This statement based on the F-statistic that is provided in the tables 10, 11, 12, and 13, reflecting probability of below $5 \%$ significance level. This means that all variables both in the short and long run effect affect inflation. It is quite disappointing since the work of some Islamic thinker like Meera (2006,2009); Iqbal and Mirakhor (2011); Ascarya (2014); Askari and Krichene (2016), as well as Syamlan (2016) actually opined that Islamic Bank should not operate under FRBS. Besides that, this impact of SRR as well as mismatch to the economy are also in line with the paper that have been written by Austrian School economist that are mentioned in the literature review.

To obtain the responses from the other variable shocks, an Impulse Response Function analysis is used (see Fig. 3). 


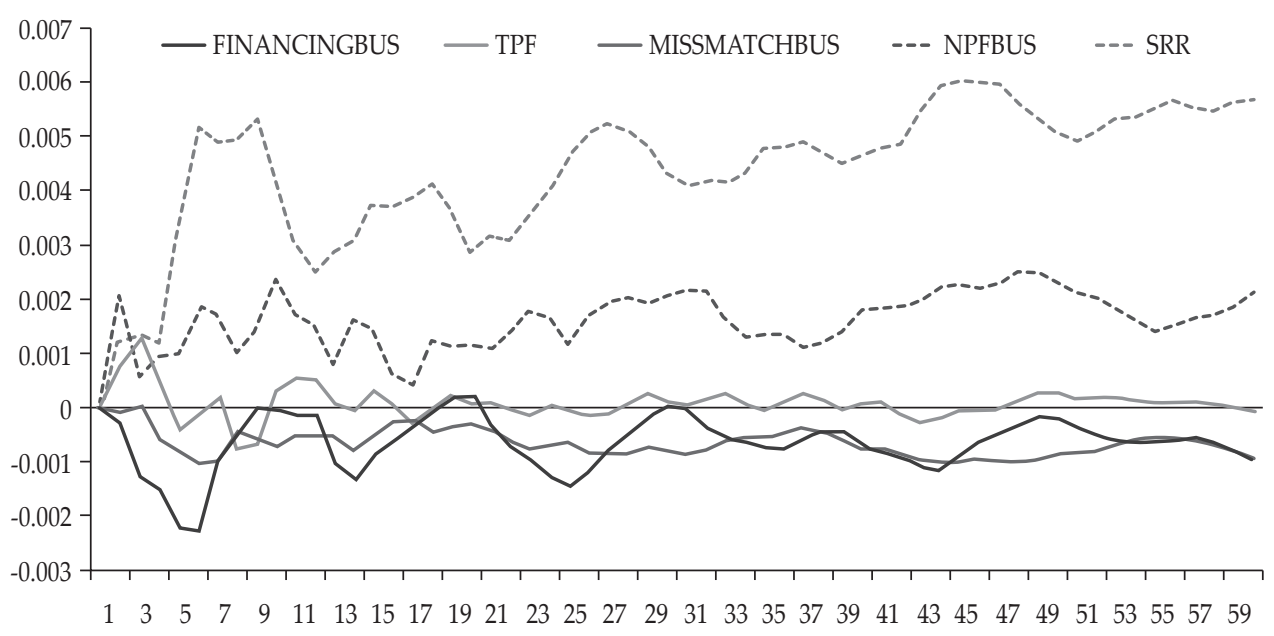

Source: Running Eviews 9.0 (Authors, 2018)

Figure 3. IRF of BUS Model

Fig. 3 indicates the IRF results that occur in the BUS equation. The SRR variable responds positively by having shock that is spanned around 0.0000 to 0.0057 within next 60 -month period and the shock will be arrived in the peak 0.006028 at $45^{\text {th }}$ month. The FINANCINGBUS variable responds negatively by having shock that is spanned around 0.0000 to -0.000981 within next 60 -month period and the shock will be arrived in the peak 0.009478 at $28^{\text {th }}$ month. The TPF variable responds positively by having shock that is spanned around 0.0000 to 0.0000056 within next 60-month period and the shock will be arrived in the peak 0.0002716 at $53^{\text {rd }}$ month. The NPFBUS variable responds positively by having shock that is spanned around 0.0000 to 0.00289 within next 60 -month period and the shock will be arrived in the peak 0.002529 at $51^{\text {rd }}$ month. The MISSMATCHBUS variable responds negatively by having shock that is spanned around 0.0000 to 0.0009231 within next 60 -month period and the shock will be arrived in the peak 0.0009880 at $48^{\text {th }}$ month. after inflation and began to stabilize in the 13th period. So when the Reserve Requirement increased, the inflation also increased. The MISBUS variable responds positively by the INF variable of 0.0009 and began to stabilize again in the 10th period. So when the mismatch ratio is increasing, the inflation will also increase. Likewise for the variable DPKBUS, which responded positively by the INF of 0.0021 and began to stabilize in the 14th period and for PBYBUS variables which also responded positively by the INF and stabilized in the 15th period.

The INF variable responds negatively to the NPF BUS variable shock of -0.00048 . This means that if the NPF at an Islamic Commercial Bank has increased, inflation will decline. 


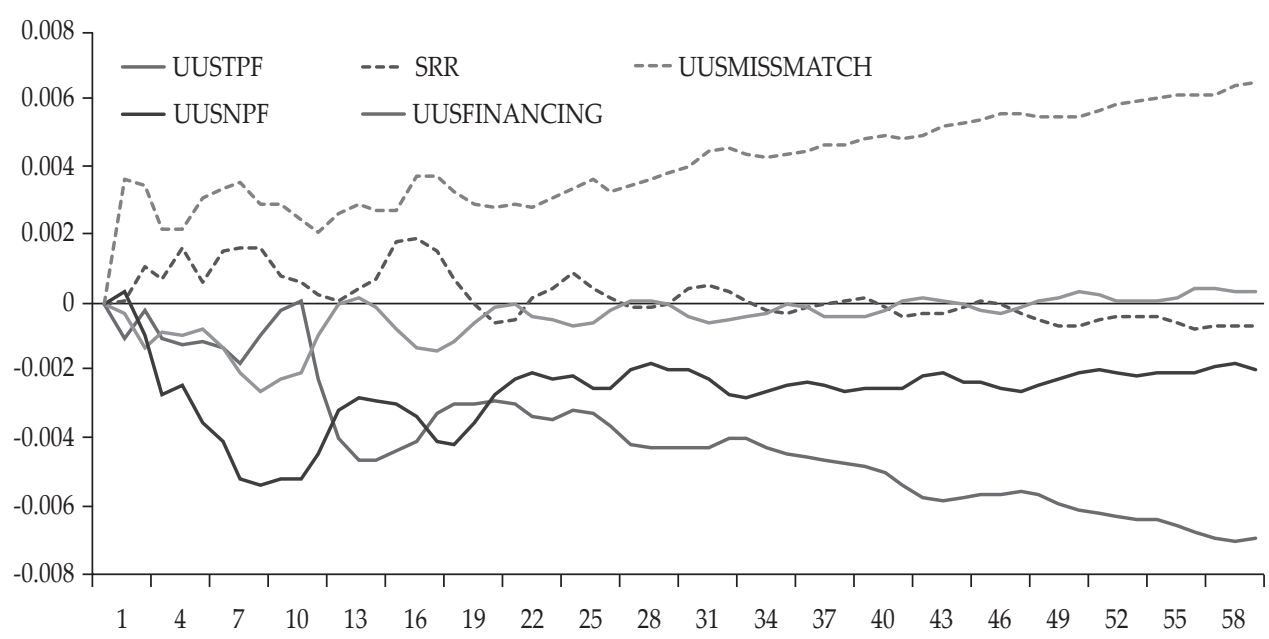

Source: Running Eviews 9.0 (Authors, 2018)

Figure 4. IRF of UUS Model

Fig. 4 shows the IRF results that occur in the UUS equation. The SRR variable responds negatively by having shock that is spanned around 0.0000 to 0.000637 within next 60 month period and the shock will be arrived in the peak 0.000655 at $42^{\text {th }}$ month. The UUSTPF variable responds positively by having shock that is spanned around 0.0000 to 0.006946 within next 60 -month period and the shock will be arrived in the peak 0.006946 at $59^{\text {th }}$ month. The UUSFINANCING variable responds positively by having shock that is spanned around 0.0000 to 0.000341 within next 60-month period and the shock will be arrived in the peak 0.000456 at $53^{\text {rd }}$ month. The UUSNPF variable responds positively by having shock that is spanned around 0.0000 to 0.0019 within next 60 -month period and the shock will be arrived in the peak 0.004119 at $22^{\text {nd }}$ month. The UUSMISSMATCH variable responds positively by having shock that is spanned around 0.0000 to 0.006518 within next 60 -month period and the shock will be arrived in the peak 0.006518 at $60^{\text {th }}$ month.

To see the amount of contribution given by each variable, the writer analyzes Forecast Error Variance Decomposition (FEVD). The results of the FEVD test analysis can be seen from the following figure. 


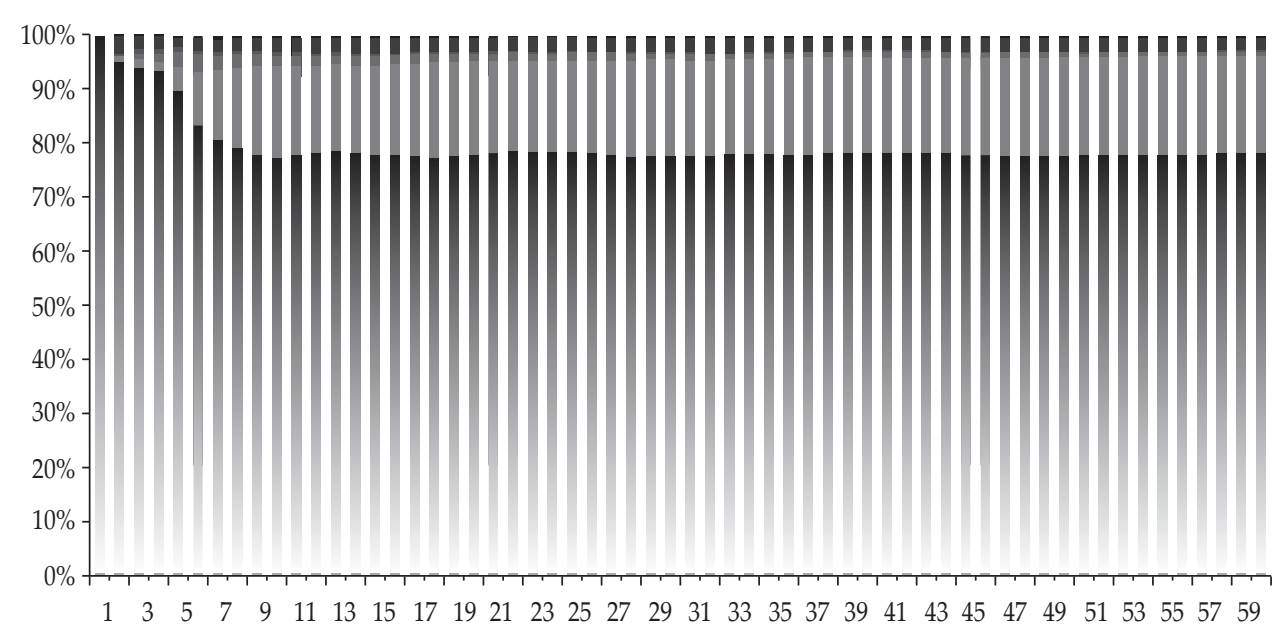

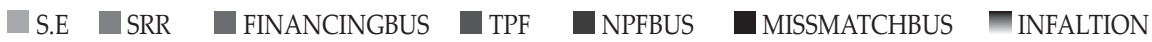

Source: Running Eviews 9.0 (Authors, 2018)

Figure 5. FEDV of BUS Model

It can be seen in the BUS equation that there are 2 aspects from the variables that give a significant contribution to inflation. $R R$ is the variable that gives the largest contribution and reached 18.274 percent. NPFBUS is the variable that gives the second largest contribution and reached 2.54 percent. FINANCINGBUS is the variable that gives contribution and peaks at 0.59 . MISSMATCHBUS is the variable that gives the contribution and reaches 0.429 percent. TPF is the variable that gives the lowest contribution and reached $0.08 \%$ percent.

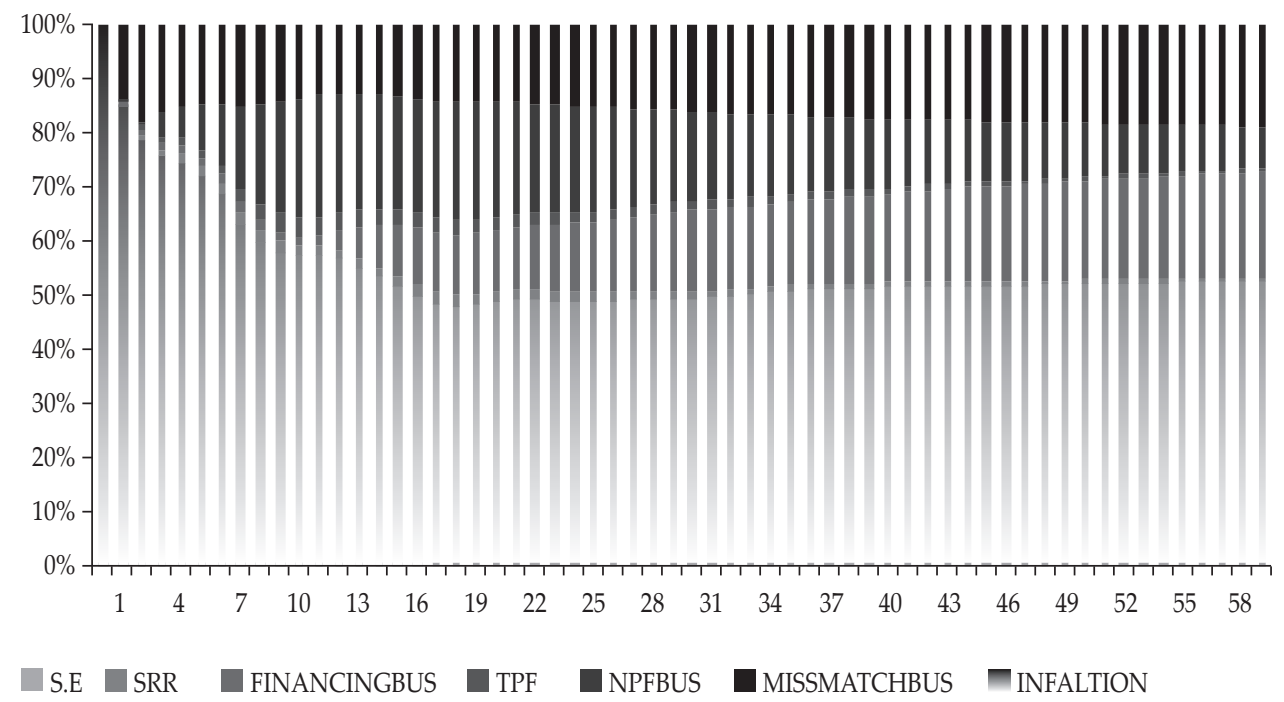

Source: Running Eviews 9.0 (Authors, 2018)

Figure 6. FEDV of UUS Model 
From the picture above, it can be seen in the BUS equation that there are 3 aspects from the variables that give a significant contribution to inflation. UUSTPF is the variable that gives the largest contribution and reached 19.81 percent. UUSMISSMATCH is the variable that gives the second largest contribution and reached 19.027 percent. UUSNPF is the variable that gives third largest contribution and reached 7.69 percent. UUSFINANCING is the variable that supplies the contribution and reached 0.57 percent. UUSFINANCING is the variable that gives the contribution and reached 0.53 percent.

\section{CONCLUSIONS AND RECOMMENDATIONS}

\subsection{Conclusions}

Based on the results of the research and discussion, the conclusions are as follows:

1. Both Indonesian Islamic Banks, BUS and UUS, practiced FRBS since the observed period of June 2014 to the September 2018. There are two variables consistently significant to the inflation: SRR and Mismatch both in BUS - UUS Model and short- and long- run relationships. Besides, based on the ECM result, the functioning of UUS provides significant effect to the inflation if we compare to the BUS.

2. Reserve Requirement, Third Party Funds, Mismatch Ratios, and Nonperforming Financing on BUS contribute significantly to inflation. In contrast to the UUS, only the Third Party Funds and Mismatch Ratios contribute significantly to inflation.

3. UUS has more influence than BUS because there are 3 variables affecting inflation both in the long-term and short-term variables, including Mismatch ratio, total financing, and total third party funds. Whereas in BUS, there is only the Non-performing Financing which has both short and long-term effects on inflation. Then, in BUS and UUS both Third Party Funds and Mismatch Ratios contribute to inflation. Third Party Funds in BUS contributes more than UUS to Inflation. Mismatch Ratio on BUS contributes less than the Mismatch Ratio on UUS.

Based on the above explanations, Islamic Banking in Indonesia is currently practicing the Fractional Reserve Banking System.

\subsection{Recommendations}

1. For banking institutions

a. Liquidity management should reform from full of funds to an allocation of funds, which means that not all the third party funds entered may be provided with financing (Darsono et al., 2017).

b. Savings and demand deposits must be focused on short-term transactions and not for financing (Bagus et al., 2016).

c. Because savings and current accounts are not used for financing funds, it is necessary to consider whose investment accounts and whose main features of withdrawal can only be withdrawn when it is due (Syamlan, 2018). 
2. For policy makers

a. Policy makers should issue regulations to govern the amount of the banking Mismatch ratio for the Mismatch ratio in the controlled banking.

b. Policy makers should encourage banks to create investment accounts (Syamlan, 2018).

\section{REFERENCES}

Ahmed, A. E. M. (2011). The Long - Run Relationship between Money Supply, Real GDP, and Price Level : Empirical Evidence From Sudan. Journal of Business Studies Quarterly, 2(2), 68-79.

Angel, J. (2016). On The Ethics of Fractional Banking. Journal of CS, 24(3), 164-177.

Archer, S., \& Karim, R. A. A. A. (2009). Profit-Sharing Investment Accounts in Islamic Banks : Regulatory Problems and Possible Solutions. Journal of Banking Regulation, 10(4), 300-306. https://doi.org/10.1057/jbr.2009.9

Archer, S., \& Karim, R. A. A. K. (2012). The Structure, Regulation and Supervision of Islamic Banks. Journal of Banking Regulation, 13(3), 228-240. https://doi. org/10.1057/jbr.2012.3

Ascarya. (2013). Determining the Real Causes of Financial Crisis in Islamic Economic Perspective: Analytic Network Process (ANP) Approach. Tazkia Islamic Finance and Business Review, 9(2), 109-127.

Ascarya. (2014). Monetary Policy Transmission Mechanism Under Dual Financial System In Indonesia : Interest-Profit Channel. International Journal of Economics, Management and Accounting, 1(1), 1-32.

Askari, H., \& Krichene, N. (2016). 100 Percent Reserve Banking and The Path to A Single Country Gold Standard. The Quarterly Journal of Austrian Economics, 19(1), 29-64.

Bagus, P. (2012). Austrian Business Cycle Theory: Are 100 Percent Reserves Sufficient to Prevent Business Cycle? Procesos de Mercado: Revista Europa de Economia Politica, IX(1), 389-411.

Bagus, P., Gabriel, A., \& Howden, D. (2016). Reassessing the Ethicality of Some Common Financial Practices. Journal of Business Ethics, 134(December 2014), 471-480. https://doi.org/10.1007/s10551-014-2525-9

Bagus, P., \& Howden, D. (2009). The Legitimacy of Loan Maturity Mismatching: A Risky, but not Fraudulent, Undertaking. Journal of Business Ethics, 90(3), 399406. https://doi.org/10.1007/s10551-009-0050-z

Bagus, P., \& Howden, D. (2010). Fractional Reserve Free Banking: Some Quibbles. The Quarterly Journal of Austrian Economics, 13(4), 29-56.

Bagus, P., \& Howden, D. (2012a). Monetary Equilibrium and Price Stickiness : A Rejoinder. Review of Austrian Economics, 25(July), 271-277. https://doi. org/10.1007/s11138-012-0183-7

Bagus, P., \& Howden, D. (2012b). The Continuing Continuum Problem of Deposits and Loans. Journal of Business Case Studies - Spanish Edition, 106(August 2011), 295-300. https://doi.org/10.1007/s10551-011-0996-5

Bagus, P., \& Howden, D. (2016). The Economic and Legal Significance of 'Full' Deposit Availability. European Journal of Law and Economics, 243-254. https:// doi.org/10.1007/s10657-012-9347-y 
Bagus, P., Howden, D., \& Gabriel, A. (2015). Oil and Water Do Not Mix, or : Aliud Est Credere , Aliud Deponere. Journal of Business Ethics, 128, 197-206. https:// doi.org/10.1007/s10551-014-2087-x

Barnett II, W., \& Block, W. E. (2009). Time Deposits, Dimensions, and Fraud. Journal of Business Ethics, 88, 711-716. https://doi.org/10.1007/s10551-008-9976-9

Block, W., \& Garschina, K. M. (1996). Hayek, Business Cycles and Fractional Reserve Banking: Continuing The De-Homogenization Process. The Review of Austrian Economics, 9(1), 77-94. https://doi.org/10.1007/BF01101882

Cochran, J. P., \& Call, S. T. (1998). The Role of Fractional - Reserve Banking and Financial Intermediation in The Money Supply Process: Keynes and The Austrians. The Quarterly Journal of Austrian Economics, 1(3), $29-40$.

Cochran, J. P., \& Call, S. T. (2000). Free Banking and Credit Creation: Implications for Business Cycle Theory. The Quarterly Journal of Austrian Economics, 3(3), 35-50.

Darsono, Sakti, A., Ascarya, Aisyah, S., Harisman, Darwis, A., Rahmawati, S. (2017). Perbankan Syariah di Indonesia: Kelembagaan dan Kebijakan serta Tantangan ke Depan. (M. S. Antonio, Ed.) (1st ed.). Depok: PT. Rajagrafindo Persada.

Davidson, L. (2015). Ethical Differences Between Loan Maturity Mismatching and Fractional Reserve Banking : A Natural Law Approach. Journal of Business Ethics, 131, 9-18. https://doi.org/10.1007/s10551-014-2263-z

De Soto, J. H. (1995). A Critical Analysis of Central Banks and Fractional - Reserve Free Banking from the Austrian School Perspective. The Quarterly Journal of Austrian Economics, 8(2), 25-38.

De Soto, J. H. (1998). A Critical Note On Fractional - Reserve Free Banking. The Quarterly Journal of Austrian Economics, 1(4), 25-49.

De Soto, J. H. (2006). Money, Bank Credit, and Economic Cycles. (M. A. Stroup, Ed.) (English Ed). Auburn, Alabama: Ludwig Von Mises Institute.

Farooq, M. O. (2011). Qard Hasan, Wadiah/Amanah and Bank Deposits: Applications and Misapplications of Some Concepts in Islamic Banking. Arab Law Quarterly, 25(2), 115-146. https://doi.org/10.1163/157302511X553985

Furqani, H., \& Haneef, A. M. (2012). Theory Appraisal in Islamic Economic Methodology: Purposes and Criteria. Humanomics, 28(4), 270-284. https://doi. org/10.1108/08288661211277335

García, V. F., Cibils, V. F., \& Maino, R. (2004). Remedy for Banking Crises: What Chichago and Islam Have in Common. Islamic Economic Studies, 11(2), 1-22.

Hanif, M. (2011). Differences and Similarities in Islamic and Conventional Banking. International Journal of Business and Social Science, 2(2), 166-175.

Hasan, Z. (2008). Credit Creation and Control: an Unresolved Issue in Islamic Banking (No. 8130). Munich. Retrieved from http://mpra.ub.uni-muenchen.de/8130/

Hasan, Z. (2011). Money Creation and Control from Islamic Perspective (No. 28366). Munich. Retrieved from http://mpra.ub.uni-muenchen.de/28366/

Hassan, S. O. M., Echchabi, A., \& Aziz, H. A. (2015). Fractional Reserve Banking and Price Stability : Evidence from Gulf Cooperation Council ( GCC ) Countries. American Journal of Economics and Business Adminsitration, 2011-2015. https:// doi.org/10.3844/ajebasp.2015. 
Illiyin, A. R. N., \& Ascarya. (2013). Comparing Islamic and Conventional Main Determinants of Inflation and Growth in Indonesian Dual Financial System. In Brawijaya International Conference on Accounting and Business (p. 26). Malang: Department of Accounting FEB Universitas Brawijaya. Retrieved from www. multiparadigma.lecture.ub.ac.id

Iqbal, Z., \& Mirakhor, A. (2013). Economic Development and Islamic Finance. (A. Mirakhor \& Z. Iqbal, Eds.). Washington DC: World Bank: Series on Directions in Development. https://doi.org/10.1596/978-0-8213-9953-8

Ishaq, H. M., \& Mahjabeen. (2015). Impact of Fractional Reserve Banking System on the Ownership Structure of Economy. Pakistan Journal of Social Sciences (PJSS), 35(2), 619-628.

Javaid, O. (2015). Methodology of Institutional Analysis and Its Implication for Contemporary Framework of Islamic Banks. Humanomics, 31(2), 183-200. https://doi.org/10.1108/H-07-2013-0051

Javaid, O., \& Ul Hassan, M. (2013). A Comparison of Islamic and Capitalist Conception of Economic Justice. International Journal of Economics, Management and Accounting, 1(1), 1-31.

Lainà, P. (2015). Proposals for Full-Reserve Banking : A Historical Survey from David Ricardo to Martin Wolf. Economics Thought, 4(2), 1-19.

Meera, K. A. M., \& Larbani, M. (2006). Seigniorage of Fiat Money and The Maqasid alShari'ah. Humanomics, 22(2), 84-97. https://doi.org/10.1108/08288660610669383

Meera, K. A. M., \& Larbani, M. (2009). Ownership effects of fractional reserve banking: an Islamic perspective. Humanomics, 25(2), 1-25. https://doi. org/10.1108/08288660910964175

Nair, M. (2013). Fractional Reserves and Demand Deposits : Historical Evidence from an Unregulated Banking System. The Independent Review, 18(1), 77-88.

Ochaita, A. V. (2010). The Use of The Money In The Deposits Banking. Some Questions of Roman Law Within The Framework of The Present Financial Crisis. Journal of Business Case Studies - Spanish Edition, 6(7), 37-43.

Quinn, S. (1997). Goldsmith-Banking : Mutual Acceptance and Interbanker Clearing in Restoration London. Explorations In Economics History, 34(EH970682), 411432.

Selgin, G. (2012). Those dishonest goldsmiths. Financial History Review, 19(3), 269288. https://doi.org/doi:10.1017/S0968565012000169

Syamlan, Y. T. (2016). The Epistemological Perspective of Fractional Reserve Banking System 100\% Reserve Banking System: Where Should Islamic Banks Stands ? Tazkia Islamic Finance and Business Review, 10(2), 61-80. Retrieved from http://www.tifbr-tazkia.org/index.php/TIFBR/article/view/98/103

Syamlan, Y. T. (2018). Does Dual Banking Differentiate The Investment Account Requirement? Tazkia Islamic Finance and Business Review, 11(2),80-106. https:// doi.org/http://dx.doi.org/10.30993/tifbr.v11i1.132

Wan Ibrahim, W. H., \& Ismail, A. G. (2015). Conventional bank and Islamic banking as institutions : similarities and differences. Humanomics, 31(3), 272298. https://doi.org/10.1108/H-09-2013-0056 


\section{ATTACHMENT}

Table 1.

Unit Root Test Results

\begin{tabular}{|c|c|c|c|c|c|}
\hline \multicolumn{6}{|c|}{ Unit Root Test } \\
\hline & \multicolumn{2}{|c|}{ Mckinon 5\% } & \multicolumn{2}{|c|}{ T table } & \multirow{2}{*}{ Test Type } \\
\hline & level & 1 difference & level & 1 difference & \\
\hline Inflyoy & -1.7836 & -6.383612 & -2.91995 & -2.921175 & Intercept \\
\hline Financing BUS & -2.23071 & -7.652962 & -3.5005 & -3.502373 & Trend \& Intercept \\
\hline NPFbus & -2.72532 & -4.255038 & -3.50637 & -3.506374 & Trend \& Intercept \\
\hline SRR & -1.32739 & -7.160941 & -3.5005 & -3.502373 & Trend \& Intercept \\
\hline TPF & -1.98253 & -7.604808 & -3.5005 & -3.502373 & Trend \& Intercept \\
\hline MissmatchBUS & -2.41785 & -8.961695 & -3.5005 & -3.502373 & Trend \& Intercept \\
\hline Financing UUS & -1.79139 & -8.23363 & -3.5005 & -3.502373 & Trend \& Intercept \\
\hline NpfUUS & -2.44422 & -8.052847 & -3.5005 & -3.502373 & Trend \& Intercept \\
\hline TPFUUS & -0.23694 & -8.201614 & -2.91995 & -2.921175 & Intercept \\
\hline UUSMismatch & -2.95458 & -9.669638 & -3.5005 & -3.502373 & Trend \& Intercept \\
\hline
\end{tabular}

Table 2.

Unit Root Test of ECM BUS Model

Null Hypothesis: Unit root (individual unit root process)

Series: YOYINFLATION, MISSMATCHBUSDECIMAL, FINANCINGBUS, SRR, TPF, NPFBUS

Date: 11/26/18 Time: 14:25

Sample: 2014M06 2018M09

Exogenous variables: Individual effects

Automatic selection of maximum lags

Automatic lag length selection based on SIC: 0 to 3

Total number of observations: 303

Cross-sections included: 6

\begin{tabular}{lcc}
\hline Method & Statistic & Prob. $^{* *}$ \\
\hline ADF - Fisher Chi-square & 10.0579 & 0.6109 \\
ADF - Choi Z-stat & 0.55784 & 0.7115 \\
\hline
\end{tabular}

** Probabilities for Fisher tests are computed using an asymptotic Chi-square distribution. All other tests assume asymptotic normality. 
Table 3.

\section{Unit Root Test of ECM UUS Model}

Null Hypothesis: Unit root (individual unit root process)

Series: YOYINFLATION, UUSTPF, UUSNPF, UUSMISSMATCHDECIMAL, UUSFINANCING, SRR

Date: 11/26/18 Time: 14:16

Sample: 2014M06 2018M09

Exogenous variables: Individual effects

Automatic selection of maximum lags

Automatic lag length selection based on SIC: 0

Total (balanced) observations: 306

Cross-sections included: 6

\begin{tabular}{lcc}
\hline Method & Statistic & Prob. $^{* *}$ \\
\hline ADF - Fisher Chi-square & 8.92822 & 0.7090 \\
ADF - Choi Z-stat & 1.57734 & 0.9426 \\
\hline
\end{tabular}

** Probabilities for Fisher tests are computed using an asymptotic Chi-square distribution. All other tests assume asymptotic normality.

Table 4.

VAR Stability Test

\begin{tabular}{lcc}
\hline Model & Modulus range & Max Lag \\
\hline \multirow{3}{*}{ BUS Model } & 0.243917 & 2 \\
& - & \\
\hline \multirow{2}{*}{ UUS Model } & 0.625120 & 2 \\
& 0.044639 & \\
\hline
\end{tabular}

Table 5.

Optimum Lag Test Result of BUS

VAR Lag Order Selection Criteria

Endogenous variables: D(YOYINFLATION) D(SRR) D(FINANCINGBUS) D(TPF) D(NPFBUS)

D(MISSMATCHBUSDECIMAL)

Exogenous variables: C

Date: 11/26/18 Time: 10:59

Sample: 2014M06 2018M09

Included observations: 46

\begin{tabular}{lcccccc}
\hline Lag & LogL & LR & FPE & AIC & SC & HQ \\
\hline 0 & 589.8130 & NA & $3.81 \mathrm{e}-19^{*}$ & -25.38318 & $-25.14466^{*}$ & $-25.29383^{*}$ \\
1 & 607.8351 & 30.55914 & $8.45 \mathrm{e}-19$ & -24.60153 & -22.93190 & -23.97607 \\
2 & 627.7232 & 28.53512 & $1.85 \mathrm{e}-18$ & -23.90101 & -20.80027 & -22.73945 \\
3 & 650.8841 & 27.18884 & $4.02 \mathrm{e}-18$ & -23.34279 & -18.81094 & -21.64513 \\
4 & 688.4243 & 34.27591 & $6.03 \mathrm{e}-18$ & -23.40975 & -17.44679 & -21.17599 \\
5 & 774.3528 & $56.04030^{*}$ & $1.76 \mathrm{e}-18$ & $-25.58056^{*}$ & -18.18649 & -22.81069 \\
\hline
\end{tabular}

* indicates lag order selected by the criterion

LR: sequential modified LR test statistic (each test at $5 \%$ level)

FPE: Final prediction error

AIC: Akaike information criterion

SC: Schwarz information criterion

HQ: Hannan-Quinn information criterion 
Table 6.

Optimum Lag Test Results of UUS

VAR Lag Order Selection Criteria

Endogenous variables: D(YOYINFLATION) D(SRR) D(UUSTPF) D(UUSFINANCING) D(UUSNPF)

D(UUSMISSMATCHDECIMAL)

Exogenous variables: $\mathrm{C}$

Date: 11/26/18 Time: 12:45

Sample: 2014M06 2018M09

Included observations: 45

\begin{tabular}{lcccccc}
\hline Lag & LogL & LR & FPE & AIC & SC & HQ \\
\hline 0 & 596.4097 & NA & $1.62 \mathrm{e}-19$ & -26.24043 & $-25.99954^{*}$ & -26.15063 \\
1 & 618.0111 & 36.48234 & $3.12 \mathrm{e}-19$ & -25.60049 & -23.91427 & -24.97189 \\
2 & 639.3458 & 30.34263 & $6.52 \mathrm{e}-19$ & -24.94870 & -21.81715 & -23.78129 \\
3 & 662.3284 & 26.55772 & $1.47 \mathrm{e}-18$ & -24.37015 & -19.79327 & -22.66394 \\
4 & 699.4549 & 33.00136 & $2.34 \mathrm{e}-18$ & -24.42022 & -18.39801 & -22.17520 \\
5 & 772.1866 & 45.25528 & $1.28 \mathrm{e}-18$ & -26.05274 & -18.58520 & -23.26892 \\
6 & 916.1635 & $51.19178^{*}$ & $9.68 \mathrm{e}-20^{*}$ & $-30.85171^{*}$ & -21.93884 & $-27.52908^{*}$ \\
\hline
\end{tabular}

* indicates lag order selected by the criterion

LR: sequential modified LR test statistic (each test at $5 \%$ level)

FPE: Final prediction error

AIC: Akaike information criterion

SC: Schwarz information criterion

HQ: Hannan-Quinn information criterion

Table 7.

\section{BUS Cointegration Test Results}

Date: 11/26/18 Time: 11:04

Sample (adjusted): 2014M09 2018M09

Included observations: 49 after adjustments

Trend assumption: No deterministic trend

Series: D(YOYINFLATION) D(SRR) D(FINANCINGBUS) D(TPF) D(NPFBUS)

D(MISSMATCHBUSDECIMAL)

Lags interval (in first differences): 1 to 1

Unrestricted Cointegration Rank Test (Trace)

\begin{tabular}{lcccc}
\hline $\begin{array}{l}\text { Hypothesized } \\
\text { No. of CE(s) }\end{array}$ & Eigenvalue & $\begin{array}{c}\text { Trace } \\
\text { Statistic }\end{array}$ & $\begin{array}{c}\mathbf{0 . 0 5} \\
\text { Critical Value }\end{array}$ & Prob.** \\
\hline None & 0.646264 & 162.8188 & 83.93712 & 0.0000 \\
At most $1^{*}$ & 0.489108 & 111.8978 & 60.06141 & 0.0000 \\
At most $2^{*}$ & 0.405369 & 78.98949 & 40.17493 & 0.0000 \\
At most 3 & 0.392597 & 53.51863 & 24.27596 & 0.0000 \\
At most 4 * & 0.303541 & 29.08903 & 12.32090 & 0.0000 \\
At most 5 * & 0.206980 & 11.36344 & 4.129906 & 0.0009 \\
\hline
\end{tabular}

Trace test indicates 6 cointegrating eqn(s) at the 0.05 level

* denotes rejection of the hypothesis at the 0.05 level

**MacKinnon-Haug-Michelis (1999) p-values 
Table 8.

UUS Cointegration Test Results

Date: 11/26/18 Time: 12:47

Sample (adjusted): 2014M11 2018M09

Included observations: 47 after adjustments

Trend assumption: No deterministic trend (restricted constant)

Series: D(YOYINFLATION) D(SRR) D(UUSTPF) D(UUSFINANCING) D(UUSNPF)

D(UUSMISSMATCHDECIMAL)

Lags interval (in first differences): 1 to 3

Unrestricted Cointegration Rank Test (Trace)

\begin{tabular}{lcccc}
\hline $\begin{array}{l}\text { Hypothesized } \\
\text { No. of CE(s) }\end{array}$ & Eigenvalue & $\begin{array}{c}\text { Trace } \\
\text { Statistic }\end{array}$ & $\begin{array}{c}\mathbf{0 . 0 5} \\
\text { Critical Value }\end{array}$ & Prob. ${ }^{* *}$ \\
\hline None & 0.487133 & 115.4197 & 103.8473 & 0.0069 \\
At most 1 * & 0.464504 & 84.03594 & 76.97277 & 0.0131 \\
At most 2 & 0.363103 & 54.68150 & 54.07904 & 0.0441 \\
At most 3 & 0.310963 & 33.47755 & 35.19275 & 0.0757 \\
At most 4 & 0.235969 & 15.97192 & 20.26184 & 0.1757 \\
At most 5 & 0.068241 & 3.322015 & 9.164546 & 0.5223 \\
\hline
\end{tabular}

Trace test indicates 3 cointegrating eqn(s) at the 0.05 level

* denotes rejection of the hypothesis at the 0.05 level

**MacKinnon-Haug-Michelis (1999) p-values

Table 9.

Cointegration Test of Residual ECM BUS Model

Null Hypothesis: RESIDUUS has a unit root

Exogenous: Constant, Linear Trend

Lag Length: 0 (Automatic - based on SIC, maxlag=10)

\begin{tabular}{llcl}
\hline & & t-Statistic & Prob. $^{*}$ \\
\hline Augmented Dickey-Fuller test statistic & -4.045587 & 0.0131 \\
Test critical values: & $1 \%$ level & -4.148465 & \\
& $5 \%$ level & -3.500495 & \\
$10 \%$ level & -3.179617 & \\
\hline
\end{tabular}

*MacKinnon (1996) one-sided p-values.

Table 10.

Cointegration Test of Residual ECM UUS Model

Null Hypothesis: RESIDBUS has a unit root

Exogenous: Constant, Linear Trend

Lag Length: 0 (Automatic - based on SIC, maxlag=10)

\begin{tabular}{|c|c|c|}
\hline & $\mathrm{t}$-Statistic & Prob.* \\
\hline Augmented Dickey-Fuller test statistic & -3.347126 & 0.0703 \\
\hline Test critical values: $1 \%$ level & -4.148465 & \\
\hline $5 \%$ level & -3.500495 & \\
\hline $10 \%$ level & -3.179617 & \\
\hline
\end{tabular}

*MacKinnon (1996) one-sided p-values. 
Table 11.

VECM BUS Estimation Results

\begin{tabular}{|c|c|c|c|c|c|c|}
\hline \multicolumn{7}{|c|}{$\begin{array}{l}\text { Vector Error Correction Estimates } \\
\text { Date: 11/26/18 Time: 11:08 } \\
\text { Sample (adjusted): 2014M12 2018M09 } \\
\text { Included observations: } 46 \text { after adjustments } \\
\text { Standard errors in ( ) \& t-statistics in [ ] }\end{array}$} \\
\hline $\begin{array}{l}\text { Cointegrating } \\
\text { Eq: }\end{array}$ & Coint Eq1 & Coint Eq2 & Coint Eq3 & Coint Eq4 & Coint Eq5 & \\
\hline $\begin{array}{l}\text { YOY } \\
\text { INFLATION (-1) }\end{array}$ & 1.000000 & 0.000000 & 0.000000 & 0.000000 & 0.000000 & \\
\hline $\operatorname{SRR}(-1)$ & 0.000000 & 1.000000 & 0.000000 & 0.000000 & 0.000000 & \\
\hline $\begin{array}{l}\text { FINANCING } \\
\text { BUS (-1) }\end{array}$ & 0.000000 & 0.000000 & 1.000000 & 0.000000 & 0.000000 & \\
\hline $\operatorname{TPF}(-1)$ & 0.000000 & 0.000000 & 0.000000 & 1.000000 & 0.000000 & \\
\hline NPF BUS (-1) & 0.000000 & 0.000000 & 0.000000 & 0.000000 & 1.000000 & \\
\hline \multirow{3}{*}{$\begin{array}{l}\text { MISS MATCH } \\
\text { BUS DECIMAL } \\
(-1)\end{array}$} & 0.195030 & 9.511448 & -1.934549 & -3.009443 & -0.544007 & \\
\hline & $(0.02456)$ & (1.20195) & $(0.24089)$ & $(0.38867)$ & $(0.14671)$ & \\
\hline & [ 7.94198] & [7.91331] & {$[-8.03076]$} & {$[-7.74291]$} & {$[-3.70797]$} & \\
\hline \multirow[t]{3}{*}{ C } & -0.114338 & -10.37852 & -11.47537 & -11.34665 & -8.833975 & \\
\hline & $(0.00702)$ & $(0.34344)$ & $(0.06883)$ & $(0.11106)$ & $(0.04192)$ & \\
\hline & [-16.2951] & {$[-30.2194]$} & {$[-166.718]$} & [-102.170] & {$[-210.730]$} & \\
\hline $\begin{array}{l}\text { Error } \\
\text { Correction: }\end{array}$ & $\begin{array}{c}\text { D (YOY } \\
\text { INFLATION) }\end{array}$ & D (SRR) & $\begin{array}{c}\mathrm{D} \\
\text { (FINANCING } \\
\text { BUS) }\end{array}$ & $\mathrm{D}$ (TPF) & D (NPF BUS) & $\begin{array}{c}\text { D (MISS } \\
\text { MATCH BUS } \\
\text { DECIMAL) }\end{array}$ \\
\hline \multirow[t]{3}{*}{ Coint Eq1 } & -0.95437 & 4.423737 & -0.650324 & -0.332689 & 18.29991 & 12.73466 \\
\hline & $(0.99204)$ & $(26.8850)$ & $(1.62235)$ & $(1.85709)$ & $(4.72680)$ & $(5.51106)$ \\
\hline & {$[-0.96203]$} & [0.16454] & {$[-0.40085]$} & {$[-0.17914]$} & [3.87153] & [2.31075] \\
\hline \multirow[t]{3}{*}{ Coint Eq2 } & -0.002859 & -0.05854 & -0.036699 & 0.005145 & -0.276207 & -0.25161 \\
\hline & $(0.01755)$ & $(0.47565)$ & $(0.02870)$ & $(0.03286)$ & $(0.08363)$ & $(0.09750)$ \\
\hline & {$[-0.16290]$} & {$[-0.12307]$} & [-1.27859] & [0.15660] & {$[-3.30283]$} & [-2.58055] \\
\hline \multirow[t]{3}{*}{ Coint Eq3 } & -0.705621 & 2.617232 & -1.119094 & 1.650419 & 1.290173 & -1.512659 \\
\hline & $(0.43644)$ & (11.8278) & $(0.71374)$ & $(0.81702)$ & $(2.07952)$ & $(2.42455)$ \\
\hline & [-1.61677] & {$[0.22128]$} & [-1.56793] & [2.02006] & {$[0.62042]$} & {$[-0.62389]$} \\
\hline \multirow[t]{3}{*}{ Coint Eq4 } & 0.397301 & -1.311931 & 0.593405 & -1.044939 & -0.319801 & 1.528292 \\
\hline & $(0.25302)$ & $(6.85696)$ & $(0.41378)$ & $(0.47365)$ & $(1.20556)$ & $(1.40559)$ \\
\hline & [1.57025] & {$[-0.19133]$} & [1.43412] & {$[-2.20615]$} & {$[-0.26527]$} & [1.08730] \\
\hline \multirow[t]{3}{*}{ Coint Eq5 } & -0.045899 & 0.230830 & -0.12643 & -0.119918 & -1.008551 & -0.472371 \\
\hline & $(0.06925)$ & $(1.87677)$ & $(0.11325)$ & $(0.12964)$ & $(0.32997)$ & $(0.38471)$ \\
\hline & {$[-0.66279]$} & [0.12299] & {$[-1.11636]$} & {$[-0.92501]$} & {$[-3.05653]$} & [-1.22785] \\
\hline \multirow{3}{*}{$\begin{array}{l}\text { D (YOY } \\
\text { INFLATION } \\
(-1))\end{array}$} & 0.938133 & 12.30592 & -0.566807 & -0.317959 & -12.85684 & -11.0577 \\
\hline & $(0.78570)$ & (21.2932) & $(1.28491)$ & (1.47084) & $(3.74367)$ & $(4.36481)$ \\
\hline & [1.19400] & [0.57793] & {$[-0.44112]$} & {$[-0.21618]$} & [-3.43429] & {$[-2.53337]$} \\
\hline \multirow{3}{*}{$\begin{array}{l}\text { D (YOY } \\
\text { INFLATION } \\
(-2))\end{array}$} & -0.155226 & -7.517283 & 0.199854 & -0.725188 & -6.575783 & -7.743858 \\
\hline & $(0.62082)$ & (16.8248) & (1.01528) & (1.16218) & $(2.95806)$ & (3.44886) \\
\hline & {$[-0.25003]$} & {$[-0.44680]$} & [0.19685] & {$[-0.62399]$} & {$[-2.22300]$} & [-2.24534] \\
\hline
\end{tabular}




\begin{tabular}{|c|c|c|c|c|c|c|}
\hline $\begin{array}{l}\text { Error } \\
\text { Correction: }\end{array}$ & $\begin{array}{c}\text { D (YOY } \\
\text { INFLATION) }\end{array}$ & $\mathrm{D}$ (SRR) & $\begin{array}{c}\mathrm{D} \\
\text { (FINANCING } \\
\text { BUS) }\end{array}$ & D (TPF) & D (NPF BUS) & $\begin{array}{c}\text { D (MISS } \\
\text { MATCH BUS } \\
\text { DECIMAL) }\end{array}$ \\
\hline \multirow{3}{*}{$\begin{array}{l}\text { D (YOY } \\
\text { INFLATION } \\
(-3))\end{array}$} & 0.417867 & -8.939757 & -0.214823 & 0.528222 & -4.987151 & -3.188752 \\
\hline & $(0.41156)$ & (11.1537) & $(0.67306)$ & $(0.77045)$ & $(1.96099)$ & $(2.28636)$ \\
\hline & [1.01532] & {$[-0.80151]$} & {$[-0.31918]$} & [0.68560] & {$[-2.54318]$} & {$[-1.39469]$} \\
\hline \multirow{3}{*}{$\begin{array}{l}\text { D (YOY } \\
\text { INFLATION } \\
(-4))\end{array}$} & 0.207243 & 12.61259 & 0.263238 & -0.929658 & -9.131084 & -5.937084 \\
\hline & $(0.62330)$ & (16.8919) & (1.01933) & $(1.16682)$ & (2.96987) & $(3.46262)$ \\
\hline & [0.33249] & {$[0.74666]$} & {$[0.25825]$} & {$[-0.79674]$} & {$[-3.07458]$} & {$[-1.71462]$} \\
\hline \multirow{3}{*}{$\begin{array}{l}\text { D (YOY } \\
\text { INFLATION } \\
(-5))\end{array}$} & 0.076748 & 7.216020 & -0.492754 & 0.421487 & -1.825719 & -4.922376 \\
\hline & $(0.44507)$ & (12.0618) & $(0.72785)$ & $(0.83317)$ & (2.12064) & $(2.47250)$ \\
\hline & [0.17244] & [0.59826] & {$[-0.67699]$} & [0.50588] & {$[-0.86093]$} & [-1.99085] \\
\hline \multirow[t]{3}{*}{$\mathrm{D}(\mathrm{SRR}(-1))$} & 0.014659 & -0.19968 & 0.086336 & 0.044438 & -0.145662 & 0.163288 \\
\hline & $(0.02048)$ & $(0.55511)$ & $(0.03350)$ & $(0.03834)$ & $(0.09760)$ & $(0.11379)$ \\
\hline & [0.71567] & {$[-0.35971]$} & [2.57738] & [1.15891] & [-1.49248] & [1.43500] \\
\hline \multirow[t]{3}{*}{$\mathrm{D}(\operatorname{SRR}(-2))$} & 0.042156 & 0.320951 & 0.047381 & 0.009099 & -0.317279 & -0.038007 \\
\hline & $(0.01971)$ & $(0.53404)$ & $(0.03223)$ & $(0.03689)$ & $(0.09389)$ & $(0.10947)$ \\
\hline & [2.13928] & [0.60098] & [1.47025] & {$[0.24666]$} & {$[-3.37916]$} & {$[-0.34719]$} \\
\hline \multirow[t]{3}{*}{$\mathrm{D}(\mathrm{SRR}(-3))$} & 0.028019 & 0.033809 & 0.058466 & -0.009644 & -0.198513 & -0.044737 \\
\hline & $(0.01923)$ & $(0.52123)$ & $(0.03145)$ & $(0.03600)$ & $(0.09164)$ & $(0.10685)$ \\
\hline & [1.45682] & [0.06486] & [1.85882] & {$[-0.26784]$} & {$[-2.16621]$} & {$[-0.41871]$} \\
\hline \multirow[t]{3}{*}{$\mathrm{D}(\operatorname{SRR}(-4))$} & 0.033886 & 0.148004 & 0.044895 & -0.001894 & -0.175819 & 0.003918 \\
\hline & $(0.01694)$ & $(0.45913)$ & $(0.02771)$ & $(0.03171)$ & $(0.08072)$ & $(0.09412)$ \\
\hline & [2.00014] & [0.32235] & [1.62041] & {$[-0.05973]$} & {$[-2.17805]$} & [0.04163] \\
\hline \multirow[t]{3}{*}{$\mathrm{D}(\operatorname{SRR}(-5))$} & 0.020232 & 0.013838 & -0.034855 & -0.107681 & -0.155028 & -0.045175 \\
\hline & $(0.01798)$ & $(0.48732)$ & $(0.02941)$ & $(0.03366)$ & $(0.08568)$ & $(0.09989)$ \\
\hline & [1.12512] & {$[0.02840]$} & [-1.18525] & [-3.19888] & [-1.80942] & {$[-0.45223]$} \\
\hline \multirow{3}{*}{$\begin{array}{l}\text { D (FINANCING } \\
\text { BUS }(-1))\end{array}$} & 0.498205 & -0.245337 & 0.469993 & -1.033795 & -2.110748 & -0.157106 \\
\hline & $(0.36085)$ & $(9.77926)$ & $(0.59012)$ & $(0.67551)$ & (1.71934) & (2.00462) \\
\hline & [1.38065] & {$[-0.02509]$} & [0.79644] & [-1.53040] & {$[-1.22765]$} & {$[-0.07837]$} \\
\hline \multirow{3}{*}{$\begin{array}{l}\text { D (FINANCING } \\
\text { BUS (-2)) }\end{array}$} & 0.448832 & 1.372447 & 0.313550 & -0.724595 & -2.80159 & -1.946427 \\
\hline & $(0.25853)$ & $(7.00647)$ & $(0.42280)$ & $(0.48398)$ & $(1.23185)$ & $(1.43623)$ \\
\hline & [1.73606] & [0.19588] & [0.74161] & [-1.49717] & {$[-2.27430]$} & [-1.35523] \\
\hline \multirow{3}{*}{$\begin{array}{l}\text { D (FINANCING } \\
\text { BUS }(-3))\end{array}$} & 0.452278 & -0.905415 & 0.402274 & -0.475857 & -3.147269 & -0.44408 \\
\hline & $(0.23862)$ & $(6.46688)$ & $(0.39024)$ & $(0.44670)$ & $(1.13698)$ & $(1.32562)$ \\
\hline & [1.89536] & {$[-0.14001]$} & [1.03084] & [-1.06526] & {$[-2.76810]$} & {$[-0.33500]$} \\
\hline \multirow{3}{*}{$\begin{array}{l}\text { D (FINANCING } \\
\text { BUS (-4)) }\end{array}$} & 0.489681 & 3.348324 & 0.125983 & -0.942619 & -3.83464 & -1.019679 \\
\hline & $(0.31397)$ & $(8.50875)$ & $(0.51345)$ & $(0.58775)$ & (1.49597) & $(1.74418)$ \\
\hline & [1.55966] & [0.39352] & {$[0.24537]$} & [-1.60378] & {$[-2.56331]$} & {$[-0.58462]$} \\
\hline \multirow{3}{*}{$\begin{array}{l}\text { D (FINANCING } \\
\text { BUS }(-5))\end{array}$} & 0.185916 & 4.199027 & 0.021423 & -0.645483 & -1.608536 & -1.459196 \\
\hline & $(0.22645)$ & $(6.13684)$ & $(0.37032)$ & $(0.42391)$ & (1.07895) & $(1.25797)$ \\
\hline & [0.82102] & [0.68423] & [0.05785] & [-1.52270] & [-1.49083] & [-1.15996] \\
\hline \multirow[t]{3}{*}{$\mathrm{D}(\mathrm{TPF}(-1))$} & -0.379533 & -1.494368 & -0.365088 & 0.419759 & 2.832167 & 0.630407 \\
\hline & $(0.26396)$ & $(7.15342)$ & $(0.43167)$ & $(0.49413)$ & $(1.25768)$ & (1.46635) \\
\hline & {$[-1.43786]$} & {$[-0.20890]$} & {$[-0.84577]$} & [0.84950] & [2.25190] & [0.42991] \\
\hline \multirow[t]{3}{*}{$\mathrm{D}(\operatorname{TPF}(-2))$} & -0.34465 & -1.296055 & -0.329499 & 0.298102 & 2.712318 & 1.943731 \\
\hline & $(0.17526)$ & $(4.74961)$ & $(0.28661)$ & $(0.32808)$ & $(0.83506)$ & $(0.97361)$ \\
\hline & [-1.96654] & {$[-0.27288]$} & {$[-1.14964]$} & [0.90862] & [3.24807] & [1.99642] \\
\hline
\end{tabular}




\begin{tabular}{|c|c|c|c|c|c|c|}
\hline $\begin{array}{l}\text { Error } \\
\text { Correction: }\end{array}$ & $\begin{array}{c}\text { D (YOY } \\
\text { INFLATION) }\end{array}$ & $\mathrm{D}(\mathrm{SRR})$ & $\begin{array}{c}\mathrm{D} \\
\text { (FINANCING } \\
\text { BUS) }\end{array}$ & $\mathrm{D}$ (TPF) & D (NPF BUS) & $\begin{array}{c}\text { D (MISS } \\
\text { MATCH BUS } \\
\text { DECIMAL) }\end{array}$ \\
\hline \multirow[t]{3}{*}{$\mathrm{D}(\mathrm{TPF}(-3))$} & -0.347329 & 3.246582 & -0.369688 & 0.153497 & 2.906280 & -0.02929 \\
\hline & $(0.18789)$ & $(5.09203)$ & $(0.30727)$ & $(0.35174)$ & $(0.89526)$ & $(1.04380)$ \\
\hline & [-1.84855] & [0.63758] & [-1.20312] & [0.43640] & [3.24630] & {$[-0.02806]$} \\
\hline \multirow[t]{3}{*}{$\mathrm{D}(\operatorname{TPF}(-4))$} & -0.406072 & -3.582266 & -0.430368 & 0.307211 & 4.384393 & 0.894283 \\
\hline & $(0.28232)$ & $(7.65118)$ & $(0.46170)$ & $(0.52851)$ & $(1.34520)$ & $(1.56839)$ \\
\hline & [-1.43832] & {$[-0.46820]$} & {$[-0.93213]$} & {$[0.58128]$} & [3.25930] & [0.57019] \\
\hline \multirow[t]{3}{*}{$\mathrm{D}(\operatorname{TPF}(-5))$} & -0.179307 & -5.408061 & -0.148362 & 0.401823 & 2.875413 & 1.512185 \\
\hline & $(0.23233)$ & (6.29635) & $(0.37995)$ & $(0.43492)$ & $(1.10700)$ & $(1.29067)$ \\
\hline & {$[-0.77178]$} & [-0.85892] & {$[-0.39048]$} & [0.92389] & [2.59749] & [1.17163] \\
\hline \multirow[t]{3}{*}{ D (NPF BUS(-1)) } & 0.130249 & 0.669302 & 0.121375 & 0.071525 & -0.08998 & 0.352941 \\
\hline & $(0.05560)$ & (1.50674) & $(0.09092)$ & $(0.10408)$ & $(0.26491)$ & $(0.30886)$ \\
\hline & [2.34270] & [0.44421] & [1.33492] & [0.68722] & {$[-0.33966]$} & [1.14272] \\
\hline \multirow[t]{3}{*}{ D(NPFBUS(-2)) } & 0.066288 & -0.466124 & 0.128009 & 0.057593 & -0.307002 & 0.469085 \\
\hline & $(0.06277)$ & (1.70113) & $(0.10265)$ & $(0.11751)$ & $(0.29908)$ & $(0.34871)$ \\
\hline & [1.05603] & {$[-0.27401]$} & [1.24701] & [0.49012] & {$[-1.02647]$} & [1.34521] \\
\hline \multirow[t]{3}{*}{ D(NPFBUS(-3)) } & 0.109604 & 0.993215 & 0.026787 & 0.016585 & -0.266804 & 0.154672 \\
\hline & $(0.06042)$ & $(1.63751)$ & $(0.09881)$ & $(0.11311)$ & $(0.28790)$ & $(0.33567)$ \\
\hline & [1.81394] & [0.60654] & {$[0.27109]$} & [0.14662] & {$[-0.92673]$} & [0.46079] \\
\hline \multirow[t]{3}{*}{ D(NPFBUS(-4)) } & -0.002162 & 0.573245 & 0.029370 & 0.014297 & -0.203128 & -0.022125 \\
\hline & $(0.05523)$ & (1.49672) & $(0.09032)$ & $(0.10339)$ & $(0.26315)$ & $(0.30681)$ \\
\hline & {$[-0.03915]$} & [0.38300] & {$[0.32518]$} & [0.13829] & {$[-0.77192]$} & {$[-0.07211]$} \\
\hline \multirow[t]{3}{*}{ D(NPFBUS(-5)) } & 0.036923 & 0.766654 & -0.022337 & 0.148826 & 0.020093 & -0.156487 \\
\hline & $(0.04616)$ & $(1.25093)$ & $(0.07549)$ & $(0.08641)$ & $(0.21993)$ & $(0.25642)$ \\
\hline & [0.79992] & [0.61287] & {$[-0.29591]$} & [1.72234] & {$[0.09136]$} & {$[-0.61026]$} \\
\hline \multirow{3}{*}{$\begin{array}{l}\text { (MISS } \\
\text { MATCH BUS } \\
(-1))\end{array}$} & 0.013789 & -0.377821 & 0.030286 & 0.022426 & -0.19567 & 0.569790 \\
\hline & $(0.04332)$ & (1.17411) & $(0.07085)$ & $(0.08110)$ & $(0.20643)$ & $(0.24068)$ \\
\hline & {$[0.31828]$} & {$[-0.32179]$} & {$[0.42747]$} & {$[0.27651]$} & {$[-0.94789]$} & [2.36744] \\
\hline \multirow{3}{*}{$\begin{array}{l}\text { D (MISS } \\
\text { MATCH BUS } \\
(-2))\end{array}$} & 0.057073 & 0.260770 & 0.090099 & -0.029294 & -0.606405 & 0.642224 \\
\hline & $(0.04488)$ & $(1.21618)$ & $(0.07339)$ & $(0.08401)$ & $(0.21382)$ & $(0.24930)$ \\
\hline & [1.27179] & [0.21442] & [1.22769] & {$[-0.34870]$} & {$[-2.83602]$} & [2.57610] \\
\hline \multirow{3}{*}{$\begin{array}{l}\text { D (MISS } \\
\text { MATCH BUS } \\
(-3))\end{array}$} & 0.030173 & 0.066875 & 0.071822 & -0.055023 & -1.05839 & 0.580997 \\
\hline & $(0.05354)$ & (1.45093) & $(0.08755)$ & $(0.10022)$ & $(0.25510)$ & $(0.29742)$ \\
\hline & {$[0.56357]$} & [0.04609] & [0.82031] & {$[-0.54900]$} & [-4.14899] & [1.95345] \\
\hline \multirow{3}{*}{$\begin{array}{l}\text { D (MISS } \\
\text { MATCH BUS } \\
(-4))\end{array}$} & 0.071585 & 1.379149 & 0.017800 & -0.080999 & -0.911888 & 0.440532 \\
\hline & $(0.05493)$ & $(1.48869)$ & $(0.08983)$ & $(0.10283)$ & $(0.26174)$ & $(0.30516)$ \\
\hline & [1.30316] & {$[0.92642]$} & [0.19814] & {$[-0.78768]$} & {$[-3.48400]$} & [1.44360] \\
\hline \multirow{3}{*}{$\begin{array}{l}\text { D (MISS } \\
\text { MATCH BUS } \\
(-5))\end{array}$} & -0.004452 & -0.001652 & 0.028358 & -0.06472 & -0.392874 & 0.306249 \\
\hline & $(0.04594)$ & $(1.24492)$ & $(0.07512)$ & $(0.08599)$ & $(0.21888)$ & $(0.25519)$ \\
\hline & {$[-0.09691]$} & {$[-0.00133]$} & {$[0.37748]$} & {$[-0.75262]$} & [-1.79495] & {$[1.20007]$} \\
\hline R-squared & 0.649003 & 0.667680 & 0.891888 & 0.908375 & 0.941512 & 0.803333 \\
\hline Adj. R-squared & -0.435897 & -0.359491 & 0.557723 & 0.625172 & 0.760730 & 0.195453 \\
\hline Sum sq. resids & 0.000543 & 0.399145 & 0.001453 & 0.001904 & 0.012338 & 0.016772 \\
\hline S.E. equation & 0.007029 & 0.190489 & 0.011495 & 0.013158 & 0.033491 & 0.039048 \\
\hline F-statistic & 0.598215 & 0.650018 & 2.669004 & 3.207504 & 5.208011 & 1.321533 \\
\hline
\end{tabular}




\begin{tabular}{lcccccc}
\hline $\begin{array}{l}\text { Error } \\
\text { Correction: }\end{array}$ & $\begin{array}{c}\text { D (YOY } \\
\text { INFLATION) }\end{array}$ & D (SRR) & $\begin{array}{c}\text { D } \\
\text { (FINANCING } \\
\text { BUS) }\end{array}$ & D (TPF) & D (NPF BUS) & $\begin{array}{c}\text { D (MISS } \\
\text { MATCH BUS } \\
\text { DECIMAL) }\end{array}$ \\
\hline Log likelihood & 195.6913 & 43.91146 & 173.0654 & 166.8490 & 123.8742 & 116.8128 \\
Akaike AIC & -6.986579 & -0.387455 & -6.002843 & -5.732564 & -3.864096 & -3.557076 \\
Schwarz SC & -5.595222 & 1.003903 & -4.611485 & -4.341206 & -2.472738 & -2.165719 \\
Mean & -0.000728 & -0.032609 & 0.006327 & 0.009155 & -0.001758 & 0.000683 \\
dependent & & & & & \\
S.D. dependent & 0.005866 & 0.163373 & 0.017284 & 0.021492 & 0.068467 & 0.043533 \\
\hline $\begin{array}{l}\text { Determinant resid covariance } \\
\text { (dof adj.) }\end{array}$ & $3.84 \mathrm{E}-22$ & & & & \\
$\begin{array}{l}\text { Determinant resid covariance } \\
\text { Log likelihood }\end{array}$ & $7.18 \mathrm{E}-26$ & & & & \\
Akaike information criterion & 939.9679 & -30.216 & & & & \\
Schwarz criterion & -20.47649 & & & & \\
\hline
\end{tabular}

Table 12.

VECM UUS Estimation Results

\begin{tabular}{lccc}
\hline Vector Error Correction Estimates & & & \\
Date: 11/26/18 Time: 12:49 & & & \\
Sample (adjusted): 2014M12 2018M09 & & & \\
Included observations: 46 after adjustments & & & \\
Standard errors in () \& t-statistics in [ ] & & & \\
\hline Cointegrating Eq: & CointEq1 & CointEq2 & CointEq3 \\
\hline YOYINFLATION(-1) & 1.000000 & 0.000000 & 0.000000 \\
SRR(-1) & 0.000000 & 1.000000 & 0.000000 \\
UUSTPF(-1) & 0.000000 & 0.000000 & 1.000000 \\
UUSFINANCING(-1) & 0.040693 & 3.356450 & -1.140798 \\
& $(0.01618)$ & $(0.70329)$ & $(0.01975)$ \\
& {$[2.51466]$} & {$[4.77247]$} & {$[-57.7641]$} \\
UUSNPF(-1) & 0.121164 & 2.859697 & -0.005362 \\
& $(0.01836)$ & $(0.79801)$ & $(0.02241)$ \\
& {$[6.59883]$} & {$[3.58354]$} & {$[-0.23929]$} \\
UUSMISSMATCHDECIMAL(-1) & -0.099023 & 10.43872 & -1.44796 \\
& $(0.09805)$ & $(4.26138)$ & $(0.11966)$ \\
& {$[-1.00992]$} & {$[2.44961]$} & {$[-12.1002]$} \\
C & -1.386665 & -69.51059 & 2.157435 \\
& $(0.14047)$ & $(6.10499)$ & $(0.17143)$ \\
& {$[-9.87158]$} & {$[-11.3859]$} & {$[12.5846]$} \\
\hline Error Correction: & D (YOY & D(SRR) & D(UUSTPF) \\
\hline CointEq1 & INFLATION) & -21.72989 & 4.195661 \\
& -1.299288 & $(10.4993)$ & $(2.06371)$ \\
& $(0.30497)$ & {$[-2.06965]$} & {$[2.03307]$} \\
\hline CointEq2 & {$[-4.26032]$} & 0.566032 & -0.122515 \\
& 0.025348 & $(0.27821)$ & $(0.05468)$ \\
& $(0.00808)$ & {$[-2.24044]$} \\
\hline
\end{tabular}




\begin{tabular}{|c|c|c|c|}
\hline Error Correction: & $\begin{array}{c}\text { D (YOY } \\
\text { INFLATION) }\end{array}$ & $\mathrm{D}(\mathrm{SRR})$ & D(UUSTPF) \\
\hline \multirow[t]{3}{*}{ CointEq3 } & 0.385665 & 7.338145 & -0.505887 \\
\hline & $(0.07988)$ & $(2.75007)$ & $(0.54055)$ \\
\hline & [ 4.82795] & [ 2.66834] & {$[-0.93588]$} \\
\hline \multirow[t]{3}{*}{ D(YOYINFLATION(-1)) } & 1.158484 & 25.69138 & -4.361517 \\
\hline & $(0.35266)$ & (12.1409) & $(2.38638)$ \\
\hline & [3.28501] & [ 2.11610] & {$[-1.82767]$} \\
\hline \multirow[t]{3}{*}{ D(YOYINFLATION(-2)) } & 0.845980 & 31.62369 & -3.935397 \\
\hline & $(0.33913)$ & $(11.6752)$ & $(2.29484)$ \\
\hline & [ 2.49456] & [ 2.70862] & {$[-1.71489]$} \\
\hline \multirow[t]{3}{*}{ D(YOYINFLATION(-3)) } & 0.532599 & 2.343198 & -4.596655 \\
\hline & $(0.27862)$ & (9.59188) & $(1.88535)$ \\
\hline & [ 1.91159$]$ & [ 0.24429$]$ & {$[-2.43809]$} \\
\hline \multirow[t]{3}{*}{ D(YOYINFLATION(-4)) } & 0.368425 & 17.71023 & -1.659189 \\
\hline & $(0.22018)$ & (7.58011) & $(1.48992)$ \\
\hline & [ 1.67329$]$ & [ 2.33641] & {$[-1.11361]$} \\
\hline \multirow[t]{3}{*}{ D(YOYINFLATION(-5)) } & 0.771504 & 27.40166 & -3.726607 \\
\hline & $(0.31247)$ & $(10.7573)$ & $(2.11442)$ \\
\hline & [2.46906] & [ 2.54726] & {$[-1.76247]$} \\
\hline \multirow[t]{3}{*}{$\mathrm{D}(\mathrm{SRR}(-1))$} & -0.038446 & -0.85171 & 0.046158 \\
\hline & $(0.01273)$ & $(0.43831)$ & $(0.08615)$ \\
\hline & {$[-3.01974]$} & [-1.94318] & [0.53577] \\
\hline \multirow[t]{3}{*}{$\mathrm{D}(\mathrm{SRR}(-2))$} & -0.018254 & -0.470447 & -0.010925 \\
\hline & $(0.00800)$ & $(0.27527)$ & $(0.05411)$ \\
\hline & [-2.28299] & {$[-1.70904]$} & {$[-0.20191]$} \\
\hline \multirow[t]{3}{*}{$\mathrm{D}(\mathrm{SRR}(-3))$} & -0.012694 & -0.0828 & 0.040375 \\
\hline & $(0.00785)$ & $(0.27008)$ & $(0.05309)$ \\
\hline & {$[-1.61802]$} & {$[-0.30657]$} & [0.76055] \\
\hline \multirow[t]{3}{*}{$\mathrm{D}(\mathrm{SRR}(-4))$} & -0.000927 & 0.100333 & -0.075149 \\
\hline & $(0.00683)$ & $(0.23530)$ & $(0.04625)$ \\
\hline & {$[-0.13556]$} & [ 0.42641$]$ & {$[-1.62487]$} \\
\hline \multirow[t]{3}{*}{$\mathrm{D}(\mathrm{SRR}(-5))$} & 0.003587 & 0.075998 & 0.049531 \\
\hline & $(0.00592)$ & $(0.20374)$ & $(0.04005)$ \\
\hline & [0.60610] & [ 0.37302$]$ & [ 1.23686$]$ \\
\hline \multirow[t]{3}{*}{ D(UUSTPF(-1)) } & -0.498157 & -8.500272 & 0.285255 \\
\hline & (0.11119) & (3.82804) & $(0.75243)$ \\
\hline & [-4.48009] & {$[-2.22053]$} & [ 0.37911] \\
\hline \multirow[t]{3}{*}{ D(UUSTPF(-2)) } & -0.373114 & -6.073418 & 0.396465 \\
\hline & $(0.09287)$ & (3.19707) & $(0.62841)$ \\
\hline & {$[-4.01779]$} & [-1.89968] & [0.63091] \\
\hline \multirow[t]{3}{*}{ D(UUSTPF(-3)) } & -0.403617 & -4.339138 & 0.574624 \\
\hline & $(0.08279)$ & (2.85013) & $(0.56021)$ \\
\hline & [-4.87532] & {$[-1.52244]$} & [ 1.02573$]$ \\
\hline \multirow[t]{3}{*}{ D(UUSTPF(-4)) } & -0.304967 & -4.617009 & 0.611571 \\
\hline & $(0.08629)$ & (2.97055) & $(0.58388)$ \\
\hline & {$[-3.53438]$} & {$[-1.55426]$} & [ 1.04742] \\
\hline
\end{tabular}




\begin{tabular}{|c|c|c|c|}
\hline Error Correction: & $\begin{array}{c}\text { D (YOY } \\
\text { INFLATION) }\end{array}$ & $\mathrm{D}(\mathrm{SRR})$ & D(UUSTPF) \\
\hline \multirow[t]{3}{*}{ D(UUSTPF(-5)) } & -0.213819 & -1.748373 & 0.799844 \\
\hline & $(0.06758)$ & $(2.32664)$ & $(0.45732)$ \\
\hline & {$[-3.16384]$} & {$[-0.75146]$} & [ 1.74899$]$ \\
\hline \multirow[t]{3}{*}{ D(UUSFINANCING(-1)) } & 0.131777 & -0.784633 & 0.521473 \\
\hline & $(0.09622)$ & $(3.31250)$ & $(0.65109)$ \\
\hline & [ 1.36956$]$ & {$[-0.23687]$} & [0.80092] \\
\hline \multirow[t]{3}{*}{ D(UUSFINANCING(-2)) } & 0.196530 & 1.978254 & -1.071547 \\
\hline & $(0.10445)$ & $(3.59598)$ & $(0.70681)$ \\
\hline & [ 1.88152$]$ & [0.55013] & {$[-1.51602]$} \\
\hline \multirow[t]{3}{*}{ D(UUSFINANCING(-3)) } & 0.210255 & 2.690911 & -0.678523 \\
\hline & $(0.11395)$ & $(3.92309)$ & $(0.77111)$ \\
\hline & [ 1.84508$]$ & [0.68592] & [-0.87993] \\
\hline \multirow[t]{3}{*}{ D(UUSFINANCING(-4)) } & 0.300561 & 4.304795 & -1.350504 \\
\hline & $(0.10984)$ & $(3.78152)$ & $(0.74328)$ \\
\hline & [ 2.73630] & [ 1.13838$]$ & [-1.81695] \\
\hline \multirow[t]{3}{*}{ D(UUSFINANCING(-5)) } & 0.014564 & -2.867426 & -1.087238 \\
\hline & $(0.10288)$ & $(3.54171)$ & $(0.69615)$ \\
\hline & [0.14157] & {$[-0.80962]$} & {$[-1.56179]$} \\
\hline \multirow[t]{3}{*}{ D(UUSNPF(-1)) } & 0.023767 & -0.564557 & 0.067626 \\
\hline & $(0.01760)$ & $(0.60606)$ & $(0.11913)$ \\
\hline & [ 1.35008$]$ & {$[-0.93152]$} & [0.56769] \\
\hline \multirow[t]{3}{*}{ D(UUSNPF(-2)) } & 0.030155 & 0.134813 & -0.087324 \\
\hline & $(0.01787)$ & $(0.61538)$ & $(0.12096)$ \\
\hline & [ 1.68702$]$ & [0.21907] & {$[-0.72194]$} \\
\hline \multirow[t]{3}{*}{ D(UUSNPF(-3)) } & -0.031637 & -1.323133 & -0.002172 \\
\hline & $(0.01742)$ & $(0.59963)$ & $(0.11786)$ \\
\hline & [-1.81641] & {$[-2.20659]$} & {$[-0.01843]$} \\
\hline \multirow[t]{3}{*}{ D(UUSNPF(-4)) } & -0.005365 & 0.112612 & -0.001944 \\
\hline & $(0.01914)$ & $(0.65893)$ & $(0.12952)$ \\
\hline & {$[-0.28030]$} & [0.17090] & {$[-0.01501]$} \\
\hline \multirow[t]{3}{*}{ D(UUSNPF(-5)) } & 0.020314 & 1.035268 & -0.262451 \\
\hline & $(0.02122)$ & $(0.73066)$ & $(0.14362)$ \\
\hline & [ 0.95712$]$ & [1.41689] & {$[-1.82744]$} \\
\hline \multirow[t]{3}{*}{ D(UUSMISSMATCH (-1)) } & 0.442878 & 9.068665 & 0.091296 \\
\hline & $(0.08593)$ & $(2.95841)$ & $(0.58150)$ \\
\hline & [ 5.15375] & [3.06539] & [0.15700] \\
\hline \multirow[t]{3}{*}{ D(UUSMISSMATCH (-2)) } & 0.377517 & 6.998366 & 0.536904 \\
\hline & $(0.09186)$ & $(3.16262)$ & $(0.62163)$ \\
\hline & [ 4.10948$]$ & [ 2.21284] & [ 0.86370$]$ \\
\hline \multirow[t]{3}{*}{ D(UUSMISSMATCH (-3)) } & 0.267539 & 3.337889 & 0.305063 \\
\hline & $(0.08078)$ & $(2.78113)$ & $(0.54665)$ \\
\hline & [3.31180] & [1.20019] & [0.55806] \\
\hline \multirow[t]{3}{*}{ D(UUSMISSMATCH (-4)) } & 0.176840 & 2.329243 & 0.457273 \\
\hline & $(0.06896)$ & $(2.37419)$ & $(0.46666)$ \\
\hline & [ 2.56427] & [0.98107] & [ 0.97988$]$ \\
\hline
\end{tabular}




\begin{tabular}{lccc}
\hline Error Correction: & $\begin{array}{c}\text { D (YOY } \\
\text { INFLATION) }\end{array}$ & D(SRR) & D(UUSTPF) \\
\hline D(UUSMISSMATCH (-5)) & 0.130624 & 2.667451 & 0.239564 \\
& $(0.05485)$ & $(1.88829)$ & $(0.37116)$ \\
& {$[2.38152]$} & {$[1.41263]$} & {$[0.64545]$} \\
\hline R-squared & 0.854123 & 0.777119 & 0.613951 \\
Adj. R-squared & 0.495039 & 0.228489 & -0.336323 \\
Sum sq. resids & 0.000226 & 0.267700 & 0.010342 \\
S.E. equation & 0.004168 & 0.143500 & 0.028206 \\
F-statistic & 2.378621 & 1.416471 & 0.646078 \\
Log likelihood & 215.8856 & 53.09905 & 127.9320 \\
Akaike AIC & -7.951546 & -0.873872 & -4.12748 \\
Schwarz SC & -6.639695 & 0.437980 & -2.815629 \\
Mean dependent & -0.000728 & -0.032609 & 0.018400 \\
S.D. dependent & 0.005866 & 0.163373 & 0.024400 \\
\hline Determinant resid covariance (dof adj.) & & $1.04 \mathrm{E}-21$ & \\
Determinant resid covariance & & $5.30 \mathrm{E}-25$ & \\
Log likelihood & & 894.0175 & \\
Akaike information criterion & & -29.34859 & \\
Schwarz criterion & & -20.64266 & \\
\hline
\end{tabular}

Table 13.

Long Run ECM - BUS Model

\begin{tabular}{lcccc}
\hline Variable & Coefficient & Std. Error & t-Statistic & Prob. \\
\hline SRR & 0.018352 & 0.00345 & 5.319475 & 0.0000 \\
FINANCINGBUS & -0.129761 & 0.097467 & -1.331338 & 0.1896 \\
TPF & 0.078197 & 0.061818 & 1.264948 & 0.2123 \\
NPFBUS & -0.001967 & 0.016852 & -0.116699 & 0.9076 \\
MISSMATCHBUSDECIMAL & 0.040733 & 0.021385 & 1.904778 & 0.0631 \\
C & 0.529382 & 0.571311 & 0.926609 & 0.359 \\
\hline R-squared & 0.740279 & Mean dependent var & 0.044748 \\
Adjusted R-squared & 0.712048 & S.D. dependent var & 0.015162 \\
S.E. of regression & 0.008136 & Akaike info criterion & -6.676835 \\
Sum squared resid & 0.003045 & Schwarz criterion & -6.451692 \\
Log likelihood & 179.5977 & Hannan-Quinn criter. & -6.59052 \\
F-statistic & 26.22261 & Durbin-Watson stat & 0.69973 \\
Prob(F-statistic) & 0.000000 & & \\
\hline
\end{tabular}


Table 14.

Short Run ECM - BUS Model

\begin{tabular}{lcccc}
\hline Variable & Coefficient & Std. Error & t-Statistic & Prob. \\
\hline D(SRR) & 0.016287 & 0.005664 & 2.875628 & 0.0062 \\
D(FINANCINGBUS) & -0.091374 & 0.07303 & -1.25118 & 0.2175 \\
D(TPF) & 0.052669 & 0.058955 & 0.893362 & 0.3765 \\
D(NPFBUS) & -0.022647 & 0.013142 & -1.723216 & 0.0919 \\
D(MISSMATCHBUSDECIMAL) & 0.020892 & 0.020867 & 1.001231 & 0.3222 \\
RESIDBUS(-1) & -0.343462 & 0.11567 & -2.969343 & 0.0048 \\
C & -0.000145 & 0.000965 & -0.150808 & 0.8808 \\
\hline R-squared & 0.308221 & Mean dependent var & -0.000749 \\
Adjusted R-squared & 0.213888 & S.D. dependent var & 0.00675 \\
S.E. of regression & 0.005985 & Akaike info criterion & -7.272242 \\
Sum squared resid & 0.001576 & Schwarz criterion & -7.007089 \\
Log likelihood & 192.4422 & Hannan-Quinn criter. & -7.170919 \\
F-statistic & 3.26736 & Durbin-Watson stat & 1.213743 \\
Prob(F-statistic) & 0.009592 & & \\
\hline
\end{tabular}

Table 15.

Long Run ECM - UUS Model

Dependent Variable: YOYINFLATION

Method: Least Squares

Date: 11/26/18 Time: 14:18

Sample: 2014M06 2018M09

Included observations: 52

\begin{tabular}{lcccc}
\hline Variable & Coefficient & Std. Error & t-Statistic & Prob. \\
\hline SRR & 0.028706 & 0.003791 & 7.571851 & 0.0000 \\
UUSTPF & 0.110056 & 0.032704 & 3.365237 & 0.0016 \\
UUSFINANCING & -0.110729 & 0.032059 & -3.453951 & 0.0012 \\
UUSNPF & 0.006268 & 0.010756 & 0.582713 & 0.5629 \\
UUSMISSMATCHDECIMAL & -0.084111 & 0.029921 & -2.81107 & 0.0072 \\
C & -0.170572 & 0.114014 & -1.496063 & 0.1415 \\
\hline R-squared & 0.776765 & Mean dependent var & 0.044748 \\
Adjusted R-squared & 0.752500 & S.D. dependent var & 0.015162 \\
S.E. of regression & 0.007543 & Akaike info criterion & -6.828218 \\
Sum squared resid & 0.002617 & Schwarz criterion & -6.603074 \\
Log likelihood & 183.5337 & Hannan-Quinn criter. & -6.741903 \\
F-statistic & 32.01214 & Durbin-Watson stat & 0.917256 \\
Prob(F-statistic) & 0.000000 & & \\
\hline
\end{tabular}


Table 16.

Short Run ECM - UUS Model

\begin{tabular}{lcccc}
\hline Variable & Coefficient & Std. Error & t-Statistic & Prob. \\
\hline D(SRR) & 0.017415 & 0.005438 & 3.202188 & 0.0025 \\
D(UUSTPF) & 0.065981 & 0.034981 & 1.886231 & 0.0659 \\
D(UUSFINANCING) & 0.050125 & 0.056461 & 0.887779 & 0.3795 \\
D(UUSNPF) & -0.003462 & 0.012914 & -0.268121 & 0.7899 \\
D(UUSMISSMATCHDECIMAL) & -0.078685 & 0.028923 & -2.720485 & 0.0093 \\
RESIDUUS(-1) & -0.337531 & 0.113047 & -2.985755 & 0.0046 \\
C & -0.002213 & 0.001199 & -1.845626 & 0.0717 \\
\hline R-squared & 0.437681 & Mean dependent var & -0.000749 \\
Adjusted R-squared & 0.361001 & S.D. dependent var & 0.00675 \\
S.E. of regression & 0.005396 & Akaike info criterion & -7.479438 \\
Sum squared resid & 0.001281 & Schwarz criterion & -7.214286 \\
Log likelihood & 197.7257 & Hannan-Quinn criter. & -7.378115 \\
F-statistic & 5.707896 & Durbin-Watson stat & 1.297853 \\
Prob(F-statistic) & 0.000187 & & \\
\hline
\end{tabular}

